Federal Reserve Bank of Minneapolis

Research Department Staff Report 404

April 2008

\title{
Pricing-to-Market, Trade Costs, and International Relative Prices*
}

\author{
Andrew Atkeson \\ University of California, Los Angeles \\ and Federal Reserve Bank of Minneapolis
}

Ariel Burstein

University of California, Los Angeles

\begin{abstract}
International relative prices across industrialized countries show large and systematic deviations from relative purchasing power parity. We embed a model of imperfect competition and variable markups in a quantitative model of international trade. We find that when our model is parameterized to match salient features of the data on international trade and market structure in the US, it can reproduce deviations from relative purchasing power parity similar to those observed in the data because firms choose to price-to-market. We then examine how pricing-to-market depends on the presence of international trade costs and various features of market structure.
\end{abstract}

*Atkeson: andy@atkeson.net; Burstein: arielb@econ.ucla.edu. We are grateful for financial support from the National Science Foundation under award 0752924. We thank George Alessandria, V.V. Chari, Doireann Fitzgerald, Mark Gertler, Jonathan Heathcote, Sam Kortum, Marc Melitz, John Rogers, and three anonymous referees for very useful comments and suggestions. The views expressed herein are those of the authors and not necessarily those of the Federal Reserve Bank of Minneapolis or the Federal Reserve System. 
Between 1985 and 1988, the price of manufactured goods produced by firms in the United States moved by roughly 40 percent relative to a weighted average of the prices of manufactured goods produced by firms in the main trading partners of the United States. This large movement in the US producer-price based real exchange rate (PPI-based RER) was not exceptional. Movements of a similar magnitude occurred again in the late 1990's and more recently after 2002. As these data make clear, the price of the basket of goods sold by foreign manufacturers relative to that sold by US manufacturers is very volatile. In this paper we examine two questions. First, what impact should we expect these large movements in relative producer prices to have on the relative prices of goods that are actually traded - that is, on export and import prices? And second, what impact should we expect these relative price movements to have on relative consumer prices as measured by the consumer-price based real exchange rate (CPI-based RER)?

The standard answer to our first question is based on the hypothesis of relative purchasing power parity (relative PPP) — namely, the hypothesis that the relative price of a traded good sold in two different countries should remain constant over time. ${ }^{1}$ Applied to aggregate price data, this is the hypothesis that the import prices that consumers in one country pay for another country's goods should move one-for-one with the producer prices for goods in those countries that are the sources of those imports when all of these prices are expressed in a common currency. Likewise, a country's export prices should move one-for-one with that country's producer prices. ${ }^{2}$ This hypothesis thus implies that the terms of trade, defined as the ratio of export and import prices for a country relative to its trading partners, should be as volatile as the PPI-based RER.

The standard answer to our second question is also based on the hypothesis of relative PPP. By definition, changes in the consumer price index in each country are a trade-weighted

\footnotetext{
${ }^{1}$ The hypothesis of relative purchasing power parity is a generalization of the law of one price in that it allows for price differentials across locations that are constant over time.

${ }^{2}$ This implication can be derived from a large number of open economy macroeconomic models including those of David K. Backus, Patrick K. Kehoe, and Finn Kydland (1995) and Alan C. Stockman and Linda L. Tesar (1995).
} 
average of changes in domestic producer prices and import prices. Hence, under the hypothesis of relative PPP, changes in consumer prices should be a trade-weighted average of changes in producer prices across countries. Therefore, the CPI-based RER should be smoother than the PPI-based RER, with the extent of the smoothing depending on the extent of international trade.

Data on international relative price fluctuations for developed countries, however, are not consistent with these two standard answers. First, the terms of trade for manufactured goods are substantially less volatile than the corresponding PPI-based RER for manufactured goods. Second, fluctuations in the CPI-based RER for goods are roughly the same size as those in the PPI-based real exchange rate for manufactured goods. Both of these observations arise because, at the aggregate level, data on export and import prices show substantial and systematic deviations from relative PPP in comparison with source country producer prices. $^{3}$ In particular, an increase in home producer prices relative to foreign producer prices is typically associated with an increase in home producer prices relative to export prices, and an increase in home import prices relative to foreign producer prices.

In this paper, we build a model of international trade and international relative prices to account for these aggregate price observations. In our model, deviations from relative PPP arise as a result of the decision of individual firms to price-to-market in response to aggregate shocks. Here we use the term pricing-to-market to refer to the decision of a single producer to change the relative price at which he sells his output abroad and at home in response to changes in international relative costs. Our model is based on two key ingredients: imperfect competition with variable markups, and international trade costs. It includes a simple yet rich model of quantity competition à la Cournot in which firms do not fully pass-through changes in their marginal costs to their prices because their optimal markup depends on their market share. We focus on the role of trade costs and various features of market structure in generating deviations from relative PPP at the aggregate level resulting from the choice

\footnotetext{
${ }^{3}$ See, for example, Beverly J. Lapham (1995) and the data presented in Section II of our paper.
} 
of individual firms to price-to-market in response to aggregate shocks.

Our model is a quantitative extension of models of international pricing in Rudiger S. Dornbusch (1987) and Paul R. Krugman (1987). We use a nested constant elasticity of substitution (CES) demand system that generates variable markups under imperfect competition. This demand system has previously been studied by Elhanan Helpman and Krugman (1985) and many others. ${ }^{4}$ Our model also builds on some recently developed models of international trade. In particular, our model nests versions of models of trade based on specialization and monopolistic competition (Helpman and Krugman 1985) and Ricardian models of trade based on comparative advantage (Dornbusch, Stanley Fischer, and Paul A. Samuelson 1977). Newly developed versions of these models include work by Jonathan Eaton and Samuel Kortum (2001); Andrew B. Bernard et al. (2003); Marc J. Melitz (2003); Eaton, Kortum and Francis Kramarz (2004); Fernando Alvarez and Robert E. Lucas Jr. (2007); and Thomas Chaney (forthcoming). We follow this recent work in using trade costs to provide a tractable quantitative account of the patterns of international trade both at the aggregate level and at the level of the individual producer. ${ }^{5}$

We show that a version of our model parameterized to match some of the main features of the data on trade volumes at both the aggregate and firm level, and to have reasonable implications for various features of market structure such as the concentration of production among producers in a market and the distribution of markups of price over marginal cost, does reproduce the two main features of the data on international relative prices that motivate this study. First, the model generates movements in the terms of trade that are substantially smaller than corresponding movements in the PPI-based RER for manufac-

\footnotetext{
${ }^{4}$ Robert C. Feenstra, Joseph E. Gagnon, and Michael M. Knetter (1996); Jiawen Yang (1997); Morten O. Ravn (2001); and Gordon M. Bodnar, Bernard Dumas, and Richard C. Marston (2002) use a similar nested CES demand system in models of exchange rate pass-through. Lapham (1995), Paul R. Bergin and Feenstra (2001), George Alessandria (2004), Giancarlo Corsetti and Luca Dedola (2005), and Rebecca Hellerstein (2006), among many others, present alternative frameworks for analyzing pass-through in models of monopolistic competition with nonconstant elasticities of demand.

${ }^{5}$ Bergin and Reuven Glick (2003) and Fabio Ghironi and Melitz (2005) also study versions of new models of international trade that can account for some features of fluctuations in international relative prices. Their main emphasis is on the role of entry and exit of firms to the export markets.
} 
tured goods. Second, the model generates movements in the CPI-based RER for goods that are very similar in magnitude to corresponding movements in the PPI-based RER for manufactured goods.

We next use the model to assess the extent to which imperfect competition with variable markups and international trade costs play essential roles in generating these results. We find that both of these features are key in reproducing our two main observations on international relative prices.

Our model can reproduce the observed aggregate deviations from relative PPP that underlie our two facts only if firms in our model practice pricing-to-market. For that, both trade costs and imperfect competition with variable markups are essential. To see that imperfect competition with variable markups is essential, observe that if firms set both domestic and export prices at constant (but perhaps different) markups over marginal cost, then shocks to the marginal cost of production leave the ratio of export prices to producer prices for each firm in each country unchanged. Hence, because price indices are constructed as weighted averages of price changes at the firm level, relative PPP holds at the aggregate level and the PPI-based RER and the terms of trade move one-for-one with each other.

The observation of incomplete pass-through of changes in costs to prices arises quite naturally in our model with imperfect competition and variable markups. However, this feature of our model is not, by itself, enough to generate pricing-to-market. To get pricingto-market, we must have that a change in costs for one firm or a group of firms leads to a change in markups for those firms that is different in each market in which these firms compete. For this, we need trade costs.

To see that trade costs are essential, observe that even if firms charge variable markups in that they do not raise prices one-for-one with a change in marginal cost, in the absence of international trade costs, firms face the same set of competitors (defined by their marginal costs) when selling at home and abroad, and thus choose identical markups and prices in both markets. Thus, without international trade costs, even in the presence of variable 
markups that lead to incomplete pass-through, we have no pricing-to-market. Hence, imperfect competition with variable markups is necessary, but not sufficient, for pricing-to-market.

In an accounting sense, to match the observation that the CPI-based RER for goods moves roughly one-to-one with the PPI-based RER, we need both that imports form a small share of the goods CPI, and the terms of trade to move substantially less than the PPIbased RER. In our model, trade costs play the key role in allowing the model to match the relatively small import share observed in US data. ${ }^{6}$

We then use the model to assess quantitatively the role of two features of market structure in generating pricing-to-market in our model. The first is the extent of within-sector cost dispersion across firms: in our model this cost dispersion determines the extent of market concentration, the distribution of markups, and the size and productivity advantages of exporting versus non-exporting firms. We find that within-sector cost dispersion is quantitatively important in generating our results. In particular, in our model it is only the large firms, and not the small firms, that practice pricing-to-market in the direction suggested by the aggregate data. We find pricing-to-market at the level of the aggregate price indices only because the pricing practices of the large firms in the model dominate the price indices. In contrast, if there is no cost dispersion across firms and all firms export, we find that there is no pricing-to-market. We view this finding that cost dispersion is essential for generating pricing-to-market under our nested CES demand system as one of our main technical contributions relative to existing literature that has used this demand system.

The second feature of market structure that we examine is the extent of export participation by firms: recent research has found that only a minority of US manufacturing plants export any output at all. ${ }^{7}$ We find that this feature of market structure is not quantitatively important in generating pricing-to-market in our model. In particular, marginal trade costs are sufficient to generate pricing-to-market.

\footnotetext{
${ }^{6}$ Doireann Fitzgerald (forthcoming) also discusses this point in detail. Burstein, Martin Eichenbaum, and Sergio Rebelo (2005) use a related argument to explain low inflation after large devaluations.

${ }^{7}$ See, for example, Bernard and J. Bradford Jensen (2004).
} 
Since the finding of pricing-to-market is sensitive to the details of our model, we do not see our model as a general theory of this pricing practice. ${ }^{8}$ Nonetheless, we view it as a useful illustration of pricing-to-market with flexible prices under a demand structure that departs only minimally from the standard constant elasticity case used in many open macroeconomy models. Note that pricing-to-market is a characteristic of the literature on exchange rates and sticky prices. ${ }^{9}$ Our work is distinguished from this literature in that here, prices are set optimally every period and not fixed by assumption. We view our model as a useful illustration that evidence of pricing-to-market can be rationalized in a model with flexible rather than sticky prices.

The structure of our paper is as follows. We first review the observations on international relative prices that are the focus of this paper. We then present our model. For simplicity, we abstract from consideration of nontradeable goods and focus on producer and consumer prices of tradeable goods. We present a parameterization of the model that roughly matches micro and macro observations on the extent of trade in US manufacturing as well as data on industry concentration and firm markups, and then consider the implications of this model for the movements in the terms of trade, the PPI-based RER, and the CPI-based RER in response to a change in the relative costs of production across countries. To illustrate the role of pricing-to-market and international trade costs in the model, we compare our results to two alternative parameterizations - one in which firms choose prices that are a constant markup of prices over marginal cost and another in which there are no international trade costs. We then explore the pricing implications of our model at the firm level. Finally, we conduct a sensitivity analysis of how our quantitative results depend on various features of market structure.

\footnotetext{
${ }^{8}$ Algebraically, pricing-to-market is a change in relative markups at which an exporter sells his output abroad and at home. Pricing-to-market is sensitive to the details of our model, since the markup change in each market depends on the shape of the second derivative of demand, as well as the equilibrium change in firms' market shares. In Atkeson and Burstein (2007), we show that pricing-to-market arises quite naturally in a model with Bertrand competition and limit pricing. These results are not general because they depend on the assumption on limit pricing.

${ }^{9}$ See, for example, Caroline M. Betts and Michael B. Devereux (2000); V.V. Chari, Kehoe, and Ellen R. McGrattan (2002); and Charles Engel (2002).
} 


\section{Data on International Relative Prices}

We begin with a short review of the definition of the price indices that we consider. As we discuss in Section IIIC, price indices are constructed directly from changes in individual prices relative to a base year. ${ }^{10}$ In particular, the change in the manufacturing PPI is a salesweighted average of the change in wholesale prices charged by manufacturing firms within a country. For the United States, this price index includes the prices that firms charge both for domestic sales and for exports. The change in the manufacturing export price index is a sales-weighted average of the change in export prices charged by manufacturing firms within a country. The change in the manufacturing import price index is an import share-weighted average of the change in prices charged for imported goods. Finally, the change in the CPI for goods is an expenditure-weighted average of the change in retail prices consumers pay for goods, including both domestically produced and imported items.

In this section, we document the two main facts that motivate our study: (1) that the terms of trade for manufactured goods are significantly less volatile than the manufacturing PPI-based real exchange rate, and (2) that the CPI-based real exchange rate for goods has roughly the same volatility as the manufacturing PPI-based real exchange rate. We then argue that these two facts arise because of systematic deviations from relative PPP for traded goods at the aggregate level - specifically as a result of systematic fluctuations in the ratio of export prices to producer prices in each country. We document the magnitude of these deviations from relative PPP in both country and sectoral level data. In our model, deviations from relative PPP at the aggregate level arise as a result of the decisions of individual firms to price-to-market. We finish this section with a short literature review of the evidence for pricing-to-market at the product level.

We now document our first main fact.

Fact 1: The manufacturing terms of trade are significantly less volatile than the manufacturing PPI-based real exchange rate.

\footnotetext{
${ }^{10}$ Specifically, the price index in period $t$ relative to a base year $0, P_{t} / P_{0}$, is given by $\sum_{i} s_{i}\left(P_{i t} / P_{i 0}\right)$, as opposed to $\sum_{i} s_{i} P_{i t} / \sum_{i} s_{i} P_{i 0}$, where $s_{i}$ is the sales weight of good $i$ and $P_{i t}$ is the corresponding price.
} 
Figure 1 displays quarterly time series, between 1985 and 2006, for the US terms of trade for manufactured goods and the US manufacturing PPI-based RER. We construct the terms of trade for manufactured goods as the ratio of manufactured export and import price indices computed by the Bureau of Labor Statistics (BLS), which are available as of 1985 . We measure the manufacturing PPI-based RER as the ratio of the US producer price index for manufactured goods to a trade-weighted average of the manufactured goods producer price indices for the trading partners of the United States, where these price indices are measured in US dollars. We use import, export, and producer price indices for manufactured goods to be consistent with our quantitative model and to avoid including oil prices that have a large impact on the volatility of the overall terms of trade for many countries (see Backus and Mario J. Crucini 2000).

It can be seen from the figure that movements in the terms of trade are significantly smaller than movements in the PPI-based RER. For example, between 1985 and 1988, the US PPI-based RER depreciated by roughly 40 percent, and the terms of trade fell by only 15 percent. Note from the figure that over the last years, the terms of trade have become even smoother relative to the PPI-based RER.

We find that this fact holds not only for US data but also for other major developed countries. In the first column of Table 1, we report the relative standard deviation of the manufacturing terms of trade and the manufacturing PPI-based RER for the United States and six additional countries using quarterly data from various sources within the period 1975-2006. We include additional results in the table for the United States for the period 1985-2006 using manufactured import and export price indices computed by the BLS using price surveys rather than unit values to construct prices at the lowest level of disaggregation in the index. We report results based on four-quarter logarithmic changes in relative prices, as well as for deviations from Hodrick-Prescott (HP) trends. The results in this table indicate that the terms of trade are consistently between one-third and two-thirds as volatile as the PPI-based RER. In addition, in column 5 of Table 1, we report the correlation of the terms 
of trade and the PPI-based RER. These correlations are consistently positive but less than one.

We now turn to our second main fact:

Fact 2: Fluctuations in CPI-based real exchange rates for goods are roughly as large as fluctuations in manufacturing PPI-based real exchange rates.

Figure 1 also displays the CPI-based RER for goods for the United States between 1985 and 2006, constructed as ratios of the goods portion of the CPI in the United States to trade-weighted averages of the goods portion of the CPI in its trading partners (see the Appendix for a description of the construction of the series in this figure). This figure clearly shows that, for US data, movements in the CPI-based RER for goods are very large, almost as large as fluctuations in the PPI-based RER for manufactured goods.

In columns 4 and 8 of Table 1, we report the relative standard deviation and the correlation of the CPI-based RER and the manufacturing PPI-based RER for the United States and six other countries (using four-quarter differences and deviations from HP trends). For the United States, in the row covering the period 1985-2006, we use only consumer prices for goods (as opposed to services) in constructing the CPI-based RER. Due to lack of data, we do not have CPI-based RERs for goods between 1975 and 2006 for all the countries in Table 1, so for this time period we use data on the overall CPI-based RER (including both goods and services). However, work by Engel (1999); Maurice Obstfeld and Kenneth Rogoff (2000); Chari, Kehoe, and McGrattan (2002); and Betts and Timothy J. Kehoe (2006), using more limited data, confirms that fluctuations in the CPI-based RER for goods are very similar to fluctuations in the overall CPI-based RER. In this table we see that the CPI-based RER consistently has roughly the same volatility as the PPI-based RER and is nearly perfectly correlated with it.

We now argue that these two facts arise as a result of systematic deviations from relative PPP at the aggregate level for goods across countries. Consider our first fact. Algebraically, 
the terms of trade are related to the PPI-based RER as follows:

$$
\left.\left(\widehat{\frac{P P I}{P P I^{*}}}\right)=\widehat{\left(\frac{E P I}{I P I}\right)}+\widehat{\left(\frac{P P I}{E P I}\right.}\right)+\left(\widehat{\frac{I P I}{P P I^{*}}}\right) .
$$

In this decomposition, $P P I / P P I^{*}$ is the PPI-based RER, EPI/IPI is the terms of trade, $P P I / E P I$ is the ratio of producer and export prices, and $I P I / P P I^{*}$ is the (trade weighted) ratio of import (foreign country export) and foreign producer prices. ${ }^{11}$ Here, hats indicate changes in the logarithm of these variables. Throughout the paper, we assume all prices are measured in terms of a common currency, and, hence, nominal exchange rates do not appear in international price ratios. From expression (1), if relative PPP holds at the aggregate level, the last two terms are zero, and the terms of trade move one-for-one with the PPIbased RER. ${ }^{12}$ Instead, in the data, we find the terms of trade move by much less than the PPI-based RER. Hence, it must be that in the data there are systematic fluctuations in the price ratios $P P I / E P I$ and $I P I / P P I^{*}$.

Likewise, consider the role of deviations from relative PPP in accounting for our second fact. If relative PPP holds at the aggregate level, then international trade should play an important role in mitigating the impact of fluctuations in relative producer prices on relative consumer prices for tradeable goods. This result can be illustrated simply in a two-country symmetric model with balanced trade that abstracts from nontraded distribution costs for goods at the retail level. Let $\widehat{P P I}_{i}$ denote the change in the logarithm of the producer price index for manufactured goods in country $i$ (recall that it includes the prices that domestic firms charge for exports as well as the prices that domestic firms charge for domestic sales).

\footnotetext{
${ }^{11}$ In the data, $P P I^{*}$ and $I P I$ are trade-weighted averages of producer and import price indices, respectively. So the change in $I P I / P P I^{*}$ is a weighted average of the change in the ratio of producer and export price indices of each trading partner.

${ }^{12}$ A similar decomposition has been studied in the sticky price literature on the fluctuations in international relative prices. Obstfeld and Rogoff (2000) have observed that if one assumes that nominal prices are stuck in the currency of the producing firm, then the ratio of nominal export prices to producer prices in each country is fixed, and hence the terms of trade and the PPI-based RER move together one-for-one with any movement in the nominal exchange rate. In contrast, if nominal prices are stuck in the currency of the country in which the good is sold, then a shift in the exchange rate leads to a shift in the ratio of export prices to domestic prices in each country and the terms of trade moves in the opposite direction as the PPI-based RER.
} 
Let $\widehat{I P I}_{i}$ and $\widehat{E P I}_{i}$ denote the change in the logarithm of the import and export price indices for manufactured goods in country $i$. In a two-country model, the export price index in country 1 corresponds to the import price index in country 2 , and vice versa. The change in the consumer price index for goods in country 1 can be approximated by

$$
{\widehat{C P I_{1}}}_{2 \mathrm{PPI}_{1}}+s_{M}\left(\widehat{I P I_{1}}-{\widehat{E P I_{1}}}\right)
$$

and that for country 2 by

$$
\widehat{C P I_{2}} \simeq \widehat{P P I}_{2}+s_{M}\left(\widehat{E P I_{1}}-\widehat{I P I_{1}}\right)
$$

where, with symmetry and balanced trade, $s_{M}$ is the share of consumption expenditure on imports in both countries. Hence, the change in the CPI-based RER for goods as a fraction of the change in the PPI-based RER is given by ${ }^{13}$

$$
\frac{\widehat{C P I_{1}}-\widehat{C P I_{2}}}{\widehat{P P I}_{1}-\widehat{P P I}_{2}} \simeq 1-2 s_{M} \frac{\widehat{E P I_{1}}-\widehat{P P I}_{1}}{\widehat{P P I}_{1}-\widehat{P P I}_{2}}
$$

This expression highlights the role of (1) a relatively low value of the import share $s_{M}$ and (2) aggregate deviations from relative PPP as key elements determining the magnitude in fluctuations in relative consumer prices of goods as a fraction of fluctuations in relative producer prices.

We now document that, indeed, there are large aggregate deviations from relative PPP measured as fluctuations in the price ratios $P P I / E P I$ and $I P I / P P I^{*}$ for our set of industrialized countries. Moreover, these changes in the ratio of export to producer prices are

\footnotetext{
${ }^{13}$ This expression will still hold in a multicountry model with asymmetric countries as long as: (1) all countries are under balanced trade in the steady state, and (2) the foreign producer and consumer price indices are computed using output-weighted (rather than trade-weighted) averages of the trading partners indices. Our finding that in the United States the CPI-based RER for goods is roughly as volatile as the PPI-based RER also holds when RERs are computed using output weights.
} 
positively correlated with fluctuations in the PPI-based RER. That is, an increase in home producer prices relative to foreign producer prices is typically associated with an increase in home producer prices relative to export prices, and an increase in home import prices relative to foreign producer prices. In columns 2-3 and 6-7 of Table 1 we report the relative standard deviations and correlations of PPI/EPI and IPI/PPI* to the PPI-based RER. These data show deviations from relative PPP at the aggregate level that are one-third to two-thirds as large as the fluctuations in the PPI-based RER, and which are strongly positively correlated with the movements in the PPI-based RER.

In our model, deviations from relative PPP at the aggregate level arise as a result of the decisions of individual firms to price-to-market. An implication of our model, then, is that deviations from relative PPP should hold in more disaggregated data. We now present evidence of substantial and systematic deviations from relative PPP using more disaggregated data on prices.

We begin with import prices disaggregated by country of origin. We consider fluctuations in $I P I / P P I^{*}$ for the United States using US manufacturing import price indices for imports from Japan, the European Union, and Canada, and corresponding source country manufacturing producer price indices, all expressed in US dollars. In Table 2, Panel A, we report the volatility and correlation of these country of origin specific measures of $I P I / P P I^{*}$ relative to fluctuations in the PPI-based RER between the United States and each of these regions over the period 1991-2006. Using these data disaggregated by country, we find results very similar to what we found for the United States at the aggregate level.

We now examine data on producer and export prices disaggregated by sector for both the United States and Japan. Specifically, we examine the volatility and correlation of sectoral measures of $P P I / E P I$ relative to the fluctuations in the overall PPI-based RER for these two countries. In Table 2, Panel B, we summarize the volatility and correlation of PPI/EPI for 39 US manufacturing four-digit SIC sectors during 1980-1992, relative to the overall US manufacturing PPI-based RER. Specifically, we report the median, the mean, 
the maximum, the minimum, and the standard deviation of these statistics across the 39 sectors for which we have data. Likewise, in Table 2, Panel C, we report the volatility and correlation of Japan's producer prices relative to export prices $(P P I / E P I)$ for seven major manufacturing industries, relative to the total manufacturing PPI-based RER in Japan over the period 1975-2006. In the US data, we find that the median and mean volatilities of PPI/EPI are roughly one-third as large as that of the overall PPI-based RER. This is similar to what we found for the United States in the aggregate data. There is, however, a great deal of heterogeneity in this measure across sectors. For the Japanese sectoral data, the fluctuations in PPI/EPI are larger relative to the overall PPI-based RER than in the US data, which, again, is consistent with the aggregate data in Table 1.

Finally, we note that several researchers have found substantial deviations from relative PPP in firm level or highly disaggregated product level price data. For example, Marston (1990) studies the response of domestic and export prices to changes in Japan's real exchange rate for 17 four-digit Japanese industries. On average, his estimates imply that the relative price of exports to domestic sales falls by roughly 50 percent of any appreciation of the RER. Knetter $(1989,1993)$ studies how prices of exports from the United States, United Kingdom, Japan, and Germany respond to changes in destination-specific RERs. He finds that the relative price that Japanese auto exporters charge for their exports to Germany compared with the price charged to the United States changes by 70 percent of any fluctuation in the Germany-US RER. Pinelopi K. Goldberg and Knetter (1997) survey recent micro studies that suggest that pricing-to-market is prevalent in the data.

\section{Model}

We develop a model in which two symmetric countries (indexed by $i=1,2$ ) produce and trade a continuum of goods subject to frictions in international goods markets. We first present our results in a version of the model that abstracts from distribution costs so as to isolate the role of trade costs and variable markups in shaping fluctuations in international relative prices. We then introduce nontradeable distribution costs to address the data on the 
CPI-based RER for goods (which include distribution costs). We consider aggregate shocks to productivity as the driving force behind fluctuations in international relative prices.

Preferences in country $i$ are given by $E_{0} \sum_{t=0}^{\infty} \beta^{t} u\left(c_{i t}, 1-l_{i t}\right)$, where $\beta$ is the discount factor and $u(c, 1-l)=\log \left[c^{\mu}(1-l)^{1-\mu}\right]$. Here $c_{i t}$ denotes final consumption and $l_{i t}$ denotes working hours of the representative household of country $i$ at time $t$. We assume that households in each country trade a complete set of international assets. In solving for equilibria, we use the following standard first-order conditions from the households' utility maximization problem:

$$
\begin{gathered}
\frac{1-\mu}{\mu} \frac{c_{i t}}{1-l_{i t}}=\frac{W_{i t}}{P_{i t}} \text { for } i=1,2 \\
\frac{c_{2 t}}{c_{1 t}}=\frac{P_{1 t}}{P_{2 t}} .
\end{gathered}
$$

Here, $W_{i t}$ and $P_{i t}$ denote the wage and the final consumption price in country $i$ at time $t$. As is standard with complete markets, these first-order conditions hold at every date and in every state of nature.

\section{A. Aggregation of Goods into Sectors}

Our model is designed to allow us to derive implications for international relative prices at both an aggregated and a disaggregated level. At the lowest level of aggregation in our model, we consider individual firms producing what we term goods. These goods are the only commodities in our model that should be interpreted as physical objects that can be traded across international borders.

We aggregate goods into categories that we term sectors. We interpret sectors in our model as corresponding to the lowest level of disaggregation of commodities used in economic censuses and price index construction. We assume that each firm in our model produces a distinct good in a specific sector. One important assumption that we make is that there are 
only a relatively small number of firms in each individual sector. We then further aggregate sectors into a consumption composite, which we call final consumption. In what follows, we describe aggregation of goods into sectors, and sectors into final consumption within a period, and for simplicity we drop the subscript $t$.

Final consumption, $c_{i}$, is produced by a competitive firm using the output of a continuum of sectors $y_{i j}$ for $j \in[0,1]$ as inputs subject to a CES production function:

$$
c_{i}=\left[\int_{0}^{1} y_{i j}^{1-1 / \eta} d j\right]^{\eta /(\eta-1)} .
$$

As is standard, the theoretical price index $P_{i}$ for final consumption is given by

$$
P_{i}=\left[\int_{0}^{1}\left(P_{i j}\right)^{1-\eta} d j\right]^{1 /(1-\eta)},
$$

and the inverse demand functions for the output of individual tradeable sectors are given by

$$
\frac{P_{i j}}{P_{i}}=\left(\frac{y_{i j}}{c_{i}}\right)^{-1 / \eta} .
$$

We now turn to the lowest level of aggregation in the model, the aggregation of goods into sectors. In each country $i$ and sector $j$, there are $K$ domestic firms selling distinct goods and an additional $K$ foreign firms that may, in equilibrium, sell goods in that sector. We use the convention that firms $k=1,2, \ldots, K$ are domestic and $k=K+1, K+2, \ldots, 2 K$ are foreign. Output in each sector is given by

$$
y_{i j}=\left[\sum_{k=1}^{2 K}\left(q_{i j k}\right)^{\frac{\rho-1}{\rho}}\right]^{\rho /(\rho-1)},
$$

where $q_{i j k}$ denotes sales in country $i$ of firm $k$ in sector $j$. Again, as is standard, the sectoral 
theoretical price index $P_{i j}$ is given by

$$
P_{i j}=\left[\sum_{k=1}^{2 K}\left(P_{i j k}\right)^{1-\rho}\right]^{1 /(1-\rho)}
$$

and the inverse demand functions for goods within a sector are given by

$$
\frac{P_{i j k}}{P_{i j}}=\left(\frac{q_{i j k}}{y_{i j}}\right)^{-1 / \rho} .
$$

\section{B. Production and International Trade Costs}

We assume that each firm has a constant returns to scale production function that has labor as the only input. The production functions for firms from country $i$ are given by $A_{i} z l$, where $z$ differs across firms and $A_{i}$ denotes aggregate productivity that affects all firms based in country $i$. Each firm in sector $j$ based in country $i$ (i.e., those with $k \leq K$ are based in country 1) draws its idiosyncratic productivity $z$ from a log-normal distribution, that is, $\log z \sim N(0, \theta)$. This idiosyncratic component of productivity is fixed over time. The marginal cost of production, exclusive of trade costs, for a firm with productivity $z$ based in country $i$ is $W_{i} /\left(A_{i} z\right)$.

In addition to the production costs, we assume that there are costs of international trade. International trade is prohibitively costly for final consumption. The output of firms can be traded, under two types of costs. We assume there is a fixed labor cost $F$ for any firm that wishes to export any of its output to the other country. We also assume that there is an iceberg type marginal cost of exporting denoted by $D \geq 1$. With this iceberg trade cost, the marginal cost for a firm with productivity $z$ based in country 1 to sell its output in country 2 is $D W_{1} /\left(A_{1} z\right)$. Note that with $D=1$, the marginal cost of sales for this firm is the same across countries.

In the model, we assume that there is an exogenously given number $K$ of domestic firms in each sector, each with idiosyncratic productivity draws $z$. For simplicity, we do not model 
the entry decisions to the domestic market. The total number of firms, both domestic and foreign, that sell positive amounts of their goods in each country is determined endogenously in equilibrium - firms will choose to export if it is profitable for them to do so.

\section{Market Structure}

We assume that the individual goods producing firms are engaged in imperfect competition. In most of the results that follow, we take as a baseline case a model of imperfect competition based on the following assumptions.

A1) Goods are imperfect substitutes: $\rho<\infty$.

A2) Goods within a sector are more substitutable than goods across sectors: $1<\eta<\rho$.

A3) Firms play a static game of quantity competition. Specifically, each firm $k$ chooses its quantity $q_{i j k}$ sold in country $i$ taking as given the quantities chosen by the other firms in the economy, as well as the domestic wage rate $\left(W_{1}\right.$ for firms with $k \leq K$ and $W_{2}$ for those with $k>K$ ), and the final consumption price $P_{i}$ and quantity $c_{i}$. Note that under this assumption, each firm does recognize that sectoral prices $P_{i j}$ and quantities $y_{i j}$ vary when that firm changes its quantity $q_{i j k}$.

We solve the model under these assumptions as follows. Suppose that only the $K$ domestic firms produce and sell in each country in sector $j$ (below we describe how we solve for the number of foreign firms that supply the domestic market in each sector). For concreteness, consider sector $j$ in country 1 . We say that a vector of quantities $q_{1 j k}$ and prices $P_{1 j k}$ are equilibrium prices and quantities in that sector if, for each firm $k=1, \ldots K$, with productivity $z_{j k}$ (the subindex $k$ reveals the source country of the firm), the quantity $q_{1 j k}$ and price $P_{1 j k}$ solve the profit maximization problem:

$$
\max _{P, q} P q-q W_{1} /\left(A_{1} z_{j k}\right)
$$


subject to the inverse demand function derived from (9) and (12):

$$
\left(\frac{P}{P_{1}}\right)=\left(\frac{q}{y_{1 j}}\right)^{-1 / \rho}\left(\frac{y_{1 j}}{c_{1}}\right)^{-1 / \eta}
$$

where $y_{1 j}$ is given by (10) with $q_{1 j k}=q$ and the other quantities $q_{1 j l}, l \neq k$, taken as given. The final consumption price $P_{1}$ and quantity $c_{1}$ are also taken as given.

The vector of equilibrium prices for the sector can be found by solving the first order conditions of this profit maximization problem given the wage rate $W_{1}$, aggregate productivity $A_{1}$, and firm productivities $z_{j k}$. These first order conditions imply

$$
\begin{gathered}
P_{1 j k}=\frac{\varepsilon\left(s_{1 j k}\right)}{\varepsilon\left(s_{1 j k}\right)-1} \frac{W_{1}}{A_{1} z_{j k}}, \text { where } \\
\varepsilon(s)=\left[\frac{1}{\rho}(1-s)+\frac{1}{\eta} s\right]^{-1},
\end{gathered}
$$

and $s_{i j k}=P_{i j k} q_{i j k} / \sum_{l=1}^{K} P_{i j l} q_{i j l}$ is the market share of firm $k$ in its sector. From (11) and (12), these market shares can be written as a function of prices

$$
s_{i j k}=\frac{\left(P_{i j k}\right)^{1-\rho}}{\sum_{l=1}^{K}\left(P_{i j l}\right)^{1-\rho}} .
$$

Hence, (15) defines $K$ nonlinear equations in the $K$ equilibrium prices $P_{i j k}$.

We use an iterative procedure to determine how many foreign firms pay the fixed trade cost to supply the domestic market. We take the levels of the wage rate, $W_{i}$, and the final consumption price $P_{i}$ and quantity $c_{i}$ as given (these are determined in general equilibrium, as described below). We assume that foreign firms consider entry sequentially in reverse order of unit costs (this is one among many other potential equilibria). We illustrate this procedure for sector $j$ in country 1 . We first solve for the equilibrium prices under the assumption that only the lowest cost producer in sector $j$ in country 2 exports his good to country 1 . In this 
case, we solve for the $K$ prices for the domestic firms using equation (15) and the one price for the lowest cost producer in country 2 (this firm is numbered $K+1$ ) using the equation

$$
P_{1 j K+1}=\frac{\varepsilon\left(s_{1 j K+1}\right)}{\varepsilon\left(s_{1 j K+1}\right)-1} \frac{D W_{2}}{A_{2} z_{j K+1}} .
$$

Note here that the iceberg trade cost $D$ scales up the marginal cost for this exporter. With these equilibrium prices, we can use (11) to compute the sectoral price, and then use (9) and (12) to compute exports $q_{1 j K+1}$ (using the value of $P_{1}^{\eta} c_{1}$ to compute sectoral output). Then we check whether, at these prices and quantities, this lowest cost exporter in country 2 earns enough profits to cover the fixed cost $W_{2} F$. If this lowest cost exporter does not earn enough to cover the fixed cost, then, in equilibrium, there are no firms in sector $j$ that export their good from country 2 to country 1 . If this lowest cost exporter does earn enough to cover the fixed cost, then we repeat the procedure above under the assumption that the two lowest cost firms in sector $j$ in country 2 export to country 1. If, at these new prices, the second lowest cost firm in country 2 does not earn a profit large enough to cover the fixed cost $W_{2} F$, then, in equilibrium, only the lowest cost firm in sector $j$ in country 2 exports to country 1. If that second lowest cost producer in country 2 does earn a profit large enough to cover the fixed cost $W_{2} F$, we repeat the procedure with the three lowest cost firms in sector $j$ in country 2. The outcome of this procedure is a set of equilibrium prices $P_{i j k}$ and a number of foreign firms supplying the domestic market in sector $j$, given fixed aggregate prices, wages, and quantities (to be determined below).

\section{General Equilibrium}

In our model, we solve a static problem for the general equilibrium prices and quantities at every date, simply as a function of the realized aggregate productivity shocks $A_{1}$ and $A_{2}$.

This is a problem of finding a fixed point in the aggregate variables $\left\{P_{i}, W_{i}, c_{i}, l_{i}\right\}_{i=1}^{2}$, where we choose $W_{2}=1$ as the numeraire. We solve this problem as follows. Given $P_{1}^{\eta} c_{1}, P_{2}^{\eta} c_{2}$, $W_{1}$ we solve for the number of firms and prices in every sector in both countries using the 
procedure described above. Aggregate and sectoral prices are then given by (8) and (11). Quantities produced by each firm are given by (9) and (12). Aggregate labor demand is constructed by adding up the implied labor demand of each firm including the fixed costs of exporting. We find a fixed point when the households' three first order conditions (5) and (6) are satisfied.

\section{E. Discussion}

The overall volume of trade in our model is determined by the tension between the gains from trade due to increased variety and the international trade costs. In our model, with $\rho<\infty$, the gains from trade are due entirely to increased variety since, by assumption, firms in each country produce a distinct set of goods. In the limit as $\rho \rightarrow \infty$, the model becomes Ricardian as the distinction between goods within a sector disappears.

Assumptions A1 and A2 are two of the key features of this model of imperfect competition that generate variable markups. The assumption A1 that $\rho<\infty$ implies that goods within a sector are imperfect substitutes so that each firm in a sector charges a distinct price for its product despite the fact that firms are engaged in quantity competition. The assumption A2 that $\rho>\eta$ implies that each firm's markup of its price over marginal cost is an increasing function of that firm's market share within its sector. This implication of the model is clearly seen in the elasticity formula (16). In one extreme, if the firm has a market share $s$ approaching zero, it perceives only the sectoral elasticity of demand $\rho$ and chooses a markup equal to $\rho /(\rho-1)$. In the other extreme, if the firm has a market share $s$ approaching one, it perceives the lower elasticity of demand across sectors $\eta$ and sets a higher markup equal to $\eta /(\eta-1)$. Firms with a sectoral market share between zero and one choose a markup that increases smoothly with that market share.

It is this assumption $\mathbf{A 2}$ together with the assumption that there are only $K<\infty$ firms in each sector that breaks the link between prices and costs in our model and gives us the possibility that firms do not pass-through changes in cost one-for-one into prices. Specifically, if a single firm or a group of firms in a sector experiences an increase in marginal cost relative 
to the other firms in the sector, this firm or group of firms loses market share and hence decreases the markup in equilibrium. As a result, the prices charged by this firm or group of firms rise by less than the increase in their costs. ${ }^{14}$ Of course, if we have a continuum of firms in each sector, then each firm has an infinitesimal market share and thus charges a constant markup of $\rho /(\rho-1)$.

Hence, with our assumptions, the observation of incomplete pass-through of changes in costs to prices arises quite naturally in our model. However, this feature of our model that generates incomplete pass-through is not, by itself, enough to generate pricing-to-market. To get pricing-to-market, we must have that a change in costs for one firm or a group of firms leads to a change in markups for those firms that is different in each market in which these firms compete. To get some intuition of how this might occur in a particular sector, imagine that in this sector, country 1 firms have 100 percent market share in their home country and 50 percent market share in country 2. We can compute the response of prices to a shock that raises $W_{1} / A_{1}$ relative to $W_{2} / A_{2}$ as follows. In country 1 , firms in this sector raise their prices for domestic sales by the full amount of the increase in costs because all firms in these sectors experience the same cost shock and hence their market shares remain unchanged. In contrast, firms in country 1 raise their export prices by less than the full cost shock because they lose market share to the firms in this sector in country 2. Hence, firms in country 1 raise their export price by less than their domestic price in response to a cost shock.

It is worth noting that if we make the alternative assumption that $\rho=\eta$, then our model reduces to the standard model of monopolistic competition with a constant markup of price over marginal cost given by $\rho /(\rho-1)$. We present results from this model with constant markups to illustrate the quantitative importance of endogenous variation in markups in our model. This model with $\rho=\eta$ and hence constant markups is related to the model studied by Ghironi and Melitz (2005). Eaton and Kortum (2002) and Alvarez and Lucas

\footnotetext{
${ }^{14}$ Note that if costs rise by the same amount for all firms in a sector, then prices also all rise by that amount, and market shares and markups remain constant.
} 
(2007) study similar models in which it is assumed that firms set prices equal to marginal cost. Our model has similar implications for the movements in international relative prices under the assumption that $\rho=\eta$, so that markups are constant, as it does under the assumption that firms set prices equal to marginal cost.

With the assumption A3 that firms engage in quantity competition, our model nests the standard Cournot model as $\rho$ gets large. This is because, as $\rho$ approaches infinity, the distinct goods in a sector become perfect substitutes and there is a single price in each country for output in that sector. This Cournot model is similar to that studied in Eaton, Kortum, and Kramarz (2004).

In this paper, we study pricing under the assumption of quantity competition. It is straightforward to solve our model under the alternative assumption that firms engage in price competition in the sense that they choose their price and quantity to maximize profits, taking the vector of prices (rather than quantities) chosen by the other firms as given. Under this alternative assumption of price competition, in equilibrium firms choose a markup of price over marginal cost as in (15), where the elasticity of demand is now given by

$$
\varepsilon(s)=\rho(1-s)+\eta s,
$$

where $s$ is the firm's market share within the sector. Note that with $\rho>\eta$, the elasticity (markup) is a decreasing (increasing) function of the firm's market share $s$. Thus, the implications of our model for markups under price competition are qualitatively similar to those under quantity competition.

If we set $\rho=\infty, F=0$, and assume that firms engage in price competition, then our model is similar to the Bertrand model studied in Bernard et al. (2003). For this Bertrand model, we can derive simple conditions for pricing-to-market to occur in equilibrium (see Atkeson and Burstein 2007). We choose to study quantity competition rather than price competition in part because our model is not continuous in its parameters under price 
competition. In particular, the equilibrium predictions of the model with large $\rho$ and $F=0$ are not similar to those of the Bertrand version of the model with $\rho=\infty$ and $F=0$. Hence, the simple intuition for pricing-to-market in the Bertrand version of the model with $\rho=\infty$ is very special and does not carry over to price competition more generally with $\rho<\infty$.

Note that in our model, if the fixed cost of exporting $F$ is equal to zero, then deviations from the law of one price are limited by iceberg costs according to: $1 / D \geq P_{1 j k} / P_{2 j k} \leq$ D. This is because markups in the export market are never larger than in the domestic market (this result relies on the assumption that $\eta$ and $\rho$ are the same in the two countries). Since equilibrium price differentials are lower than the cost of trading goods internationally, no third party has an incentive to ship goods to arbitrage these price differentials across countries. Therefore, in this case, the fact that consumers do not have incentives to arbitrage price differentials across countries is an outcome of the model, and not a consequence of assuming international market segmentation. Under the assumption that the fixed cost of exporting is positive, it is theoretically possible that international price differentials may exceed the marginal cost of shipping goods internationally. This does not occur in any of our quantitative examples.

\section{Quantitative Example}

Here we argue that a plausibly parameterized version of our model can reproduce the two main facts regarding international relative prices cited above. Specifically, we show that, in response to an exogenous shock to aggregate productivity across countries, this model implies (i) a movement in the terms of trade that is much smaller than the movement in the PPIbased RER, and (ii) a movement in the CPI-based RER that is quite large relative to the PPI-based RER.

\section{A. Choosing Benchmark Parameters}

Our model on the production side has six parameters: $K, \eta, \rho, \theta, D$, and $F$. In addition, there are two parameters in the household's utility function $(\beta$ and $\mu)$, which we set to 
the standard values $(\beta=0.96$ and $\mu=2 / 3)$. We now describe how we set the value of the production parameters.

We choose $K=20$. In our numerical simulations, we simulate prices and quantities for 400,000 firms in each country, which corresponds to 20,000 sectors. Since there are roughly 10,000 10-digit NAICS sectors, we interpret the sectors in the model as corresponding to a breakdown more disaggregated than 10-digit NAICS sectors. In Section V, we explore how our results vary with different values of $K$.

We choose $\eta$ close to 1 to keep sectoral expenditure shares roughly constant, and we set $\rho=10$. With $\rho=10$, import demand at the sectoral level in our model is quite elastic. James E. Anderson and Eric van Wincoop (2004) survey the evidence on the elasticity of demand for imports at the sectoral level and conclude that this elasticity is likely to be in the range of 5 to 10 . Our model, with $\rho=10$, is at the high end of this range.

We choose the three remaining parameters on the production side of the model $(\theta, D$, and $F$ ) to match, in a symmetric equilibrium with $A_{1}=A_{2}$, observations in the US economy on the overall volume of trade, the fraction of firms that export, and a measure of industry concentration at the sectoral level. In particular, we target three statistics. The first is the average of exports and imports relative to gross output in goods producing sectors in US data in the period 1997-2003, equal to 16.5 percent. ${ }^{15}$ The second is the fraction of US manufacturing plants that export any output at all during the period 1987-1992, equal to 25 percent. ${ }^{16}$ The third is the median Herfindahl index across sectors, which we set equal to $1500{ }^{17}$ Although we do not have comprehensive data with which to compare these implications of our model for market concentration across sectors, ${ }^{18}$ it is useful to note

\footnotetext{
${ }^{15}$ Using data from Source OECD, the average of US manufactured imports and exports as a ratio of manufactured gross output increased from 11.7 percent in 1987 to 21 percent in 2003. We choose to target the average ratio in this period, roughly equal to 16.5 percent.

${ }^{16}$ As reported in Table 1 in Bernard and Jensen (2004), the fraction of exporters in total plants was 21 percent in 1987 and 30 percent in 1992 . We choose an intermediate value of 25 percent.

${ }^{17}$ The Herfindahl index for a sector is the sum of the squared market shares of the firms in that sector, multiplied by 10,000 .

${ }^{18}$ The Census Bureau computes Herfindahl indices for manufacturing sectors down to six-digit NAICS industries using data from the Census of Manufactures. In 1997, there were 473 six-digit NAICS industries with 282 firms in the median industry and 700 firms on average in each industry. The median Herfindahl
} 
for comparison purposes that the US Department of Justice, in its merger guidelines, regards markets with a Herfindahl index below 1000 to be "unconcentrated," markets with a Herfindahl index between 1000 and 1800 as "moderately concentrated," and markets with a Herfindahl index above 1800 to be "highly concentrated." ${ }^{19}$ We regard these merger guidelines as a rough guide to the level of concentration of markets at an economically meaningful level of sectoral aggregation in the US economy. We have chosen the number 1500 so that our median sector is moderately concentrated. Our model's implications for these facts in a symmetric equilibrium are invariant to the choice of parameters in the household's utility function $(\beta$ and $\mu)$. The values of the production parameters and the corresponding facts in the US data are listed in Table $3 .^{20}$ In Section V, we discuss the sensitivity of our results to the parameters $K, \eta, \rho$, and the median Herfindahl index.

The production parameters $\theta, D$, and $F$ are related to these facts as follows. In our model, if $F=0$ and $\rho<\infty$, all firms export some of their output. Thus, a positive fixed cost of exporting is required to match the observation that only a minority of plants export. Holding fixed the other parameters and the identity of those firms that do export, variations in the marginal trade cost $D$ change the fraction of output that an exporting firm exports and hence the overall volume of trade. The parameters $\theta$ and $K$ govern the dispersion of productivities across firms, while the parameters $\eta$ and $\rho$ govern the extent to which this dispersion in productivities results in a dispersion of market shares across firms.

As a further check on our benchmark parameterization, we compare some additional implications of our model with US data.

Our macro observation on the overall volume of trade can be broken down, at the firm level, into two components: (i) the fraction of firms that export any output at all, and (ii)

index across these industries was 571, and the average of the Herfindahl indices across these industries was 737. We interpret sectors in our model as being at a lower level of aggregation than these six-digit industries and thus expect a higher level of concentration on average within our sectors.

${ }^{19}$ See, in particular, the discussion at http://www.usdoj.gov/atr/public/guidelines/horiz_book/15.html.

${ }^{20}$ The value of $D$ we use in our quantitative example is consistent with evidence on trade costs surveyed in Anderson and van Wincoop (2004). Instead of reporting F, we report in Table 3 the fraction of the labor force employed in fixed export costs activities. 
the fraction of total output that exporting firms actually export. In Table 3, we compare our model's implications for the fraction of total output that exporting firms actually export with data from Bernard et al. (2003) on the median fraction of total plant output that US exporting plants export. Here our model appears to be roughly in line with these data.

In our model with trade costs, it is the firms that draw the lowest marginal costs of production that choose to pay the costs to export. In equilibrium, these firms also tend to charge lower prices in their home market, and thus to sell more output and to have a higher market share in their home sector, than the firms that do not export. Since these exporting firms tend to have a higher market share in their home sector, from (15), we see that in the model, exporters tend to choose a higher markup of price over marginal cost. As Bernard et al. (2003) discuss in detail, this implication that exporters choose a higher markup of price over marginal cost implies that exporters have higher labor productivity measured as sales divided by employment than non-exporters. In Table 3, we present the model's implications for the median sales and measured labor productivity of firms that export versus the median sales and measured labor productivity of firms that do not export. ${ }^{21}$ We compare these implications of the model to US data cited in Bernard et al. (2003) regarding the median sales and measured labor productivity of US manufacturing plants that export versus the median sales and measured labor productivity of US manufacturing plants that do not export and to similar statistics for French firms reported in Eaton, Kortum, and Kramarz (2004). These authors examine census data on the export behavior of French firms and observe that these French data do not censor out small firms in the same way that the US data from the Census of Manufactures does. They find that median sales for exporters in these French data are 28 times the median sales for non-exporters. This is much larger than the analogous figure of 4.8 from the US data cited in Bernard et al. (2003). These statistics from our model lie between those from the US and French data.

In Table 3, we also report the sales-weighted mean markup of price over marginal cost

\footnotetext{
${ }^{21}$ We assume that the fixed costs of exporting are not counted in the calculation of labor productivity.
} 
across firms in our model. The average markup in our model is in line with average markups assumed in standard macro models (see, for example, Lawrence J. Christiano, Eichenbaum, and Charles L. Evans 2005). In Figure 2, we show a histogram of Herfindahl indices across sectors in our model and a histogram of markups across firms.

\section{B. Two Alternative Parameter Settings}

We also study the implications of our model with two alternative sets of parameter values to illustrate the key economic forces at play in our benchmark example. These alternative parameter choices, together with the model implications for these parameter choices, are also presented in Table 3 .

In our first alternative set of parameters, we set $\rho=\eta$. From (15), we see that in this case, all firms choose a constant markup of price over marginal cost of $\rho /(\rho-1)$. We refer to this parameterization of our model as the constant markup version of our model. The parameters $F$ and $D$ are chosen so that, in the symmetric equilibrium, the constant markup version of our model has the same implications for the share of exports in manufacturing output and the fraction of exporting firms as the benchmark model. The value of $\rho=\eta=3$ is roughly equal to the value used by Bernard et al. (2003). The parameters $K$ and $\theta$ are unchanged. We consider this constant markup version of our model to illustrate the role that variable markups play in shaping our model's implications for international relative prices.

In the second alternative set of parameters, we set $D=1$ and $F=0$. In this case, there are no costs of international trade. We leave the other parameters unchanged. We refer

to this parameterization of our model as the frictionless trade version of our model. We consider this frictionless trade version of our model to illustrate the role that trade frictions play in shaping our model's implications for international relative prices.

\section{The Response of Aggregate Prices to a Change in Costs}

We now consider the change in equilibrium international relative prices implied by a fall in aggregate productivity in country $1\left(A_{1}\right)$ sufficient to generate a 1 percent increase in 
aggregate costs $W_{1} / A_{1}$ in country 1 relative to aggregate costs $W_{2} / A_{2}$ in country 2 . Note that with our choice of numeraire, $W_{2}=1$, costs in country 2 do not change.

With each firm charging a distinct price, we construct in the model distinct sectoral producer price indices (following the practice of the BLS, covering prices that domestic producers charge for all sales including sales to foreigners), import price indices (covering prices that foreign firms charge for domestic sales), export price indices (covering prices that domestic firms charge for foreign sales), and consumer price indices (covering prices of domestically consumed goods, including domestically produced and imported goods). In each case, we construct price indices from the model using sales (or expenditure) weighted averages of price changes for each good. In the case of the export and import price indices, for goods that switch export or import status as a result of the shock, we attribute a price change equal to the overall change in the index. This procedure is equivalent to omitting these goods from the index and renormalizing the weights for the remaining goods. ${ }^{22}$ In the Appendix, we define the aggregate price indices that we compute in our model.

In Table 4 we report on our benchmark model's implications for the relative price movements that are the focus of our study: $(i)$ the movement in the terms of trade, and $(i i)$ the movement in the CPI-based RER, both as a percentage of the movement in PPI-based RER. We also include in the table the implications of the constant markup and the frictionless trade versions of our model for these same relative price movements.

Terms of Trade.- In row 1 of Table 4, we see that our benchmark model produces a movement in the terms of trade for country 1 that is only 53 percent as large as the movement in the PPI-based RER. In this regard, we see that our benchmark model reproduces our first fact - the terms of trade are significantly less volatile than the PPI-based RER. In our model, as in the data, this arises as a result of large deviations from relative PPP at the aggregate level. In column 1, rows 4-7 of Table 4, we report the movements in the producer price

\footnotetext{
${ }^{22}$ This is the procedure followed by the BLS in the construction of export and import price indices for the United States. See also the draft chapters of the IMF's Export and Import Price Index Manual for a detailed discussion of the construction of these price indices. These are available at www.imf.org/external/np/sta/tegeipi.
} 
index, the export price index, and the import price index for countries 1 and 2 in response to the 1 percent increase in country 1's aggregate marginal costs $W_{1} / A_{1}$. There we see that producer prices in country 1 rise by more than export prices. Note in rows 6 and 7 that the producer price index in country 2 and the import price index in country 1 also rise, with the latter rising more than the former. This is true despite the fact that there has been no change in costs in country 2. Thus, our model generates a positive correlation in the movements in $P P I_{1} / E P I_{1}$ and $I P I_{1} / P P I_{2}$ with $P P I_{1} / P P I_{2}$, as in the data. In Section IV, we show how these deviations from relative PPP at the aggregate level result from the decisions of individual firms to price-to-market.

Looking at the entries in Table 4 for the corresponding price movements for our constant markup and frictionless trade versions of the model, we see that we need both variable markups and trade frictions to deliver these implications for the terms of trade and PPIbased RER. In both of these alternative versions of our model, the movement in the terms of trade is identical to the movement in the PPI-based RER, and the ratio of export prices to producer prices is constant in both countries because relative PPP holds.

The logic behind this finding that the terms of trade move one-for-one with the relative producer prices differs across the constant markup and frictionless trade versions of our model. In the constant markup version of our model, the logic for this result is quite simple: for each firm, both domestic and export prices move one-for-one with the movement in domestic costs. Hence, relative PPP holds good by good. Note that since all prices charged by country 1 firms change by the same amount, and the change in the export price index is a weighted average of individual exporters' price changes, changes in firms' export participation have no impact in the change in the export price index. Thus, relative PPP holds in the aggregate as well. This feature of this constant markup model can be seen clearly in column 2 , rows $4-7$ of Table 4 .

For the frictionless trade version of the model, the logic for this result is more subtle. In this version of the model, markups are not constant - they vary with market share as 
described in (15). Thus, it is not the case that changes in cost are passed on fully to prices. In fact, as is shown in column 2, rows 4 and 5 of the table, there is incomplete pass-through as the firms in the country with rising wages lose market share and hence reduce their markups at home and abroad, while we see in rows 6 and 7 that the firms in country 2 with the constant costs increase their prices for domestic sales and exports. With no trade frictions, however, the set of firms and their costs competing in each sector is the same across countries, and this leads to relative PPP for each good despite imperfect competition. More specifically, each firm in a sector has the same cost for sales in each country, and hence each firm has identical market shares, identical markups, and identical prices in each country. This implies that, for each country, export prices remain constant relative to domestic producer prices, and thus, from our decomposition (1), changes in the terms of trade are identical to changes in the PPI-based RER. Hence, one can say that in the frictionless trade version of the model, there is incomplete pass-through of costs to prices, but no pricing-to-market. International trade costs are not necessary for incomplete pass-through, but they are necessary for pricing-to-market.

Note that our finding that aggregate relative PPP holds in the constant markup and frictionless examples is a theoretical result that does not depend on the value of the other parameters.

CPI-Based RER.-We now turn to our model's implications for movements in the relative price of goods across countries when these prices are measured with consumer prices rather than producer prices. In column 1, row 8 of Table 4 , we see that our benchmark model produces a movement in the CPI-based RER across countries that is 82 percent as large as the movement in the PPI-based RER.

This finding in our benchmark model that the movement in the relative consumer price across countries is quite large stands in stark contrast to the implications of the frictionless trade version of our model. As shown in column 3, row 8 of Table 4, in the frictionless trade version of our model, the CPI-based RER does not move at all. This is because, in the 
frictionless trade version of the model, relative PPP holds for each good and consumption baskets are identical across countries. Hence, the consumer price index is identical across countries. In this sense, the introduction of costs of international trade has a dramatic impact on the pricing implications of our model and moves the model much closer to the data not only in terms of its implications for traded quantities but also in terms of its implications for the CPI-based RER.

Now consider the implications of our constant markup version of the model for movements in the CPI-based RER. In column 2, row 8 of Table 4 , we see that the movement in the CPI-based RER is 67 percent of the movement in the PPI-based RER.

We can now use expression (4) to understand the results obtained in row 8, Table 4 . Under frictionless trade, the import share is $s_{M}=1 / 2$ and relative PPP holds at the aggregate level. Hence, movements in the CPI-based RER are as large as those of the PPI-based RER.

Consider now the constant markup version of our model. In that model, all goods prices move one-for-one with movements in marginal costs. Thus, relative PPP holds and both the terms of trade for country 1 and the PPI-based RER move by the change in relative costs. The ratio of the percentage movement in the CPI-based RER relative to the PPI-based RER is 67 percent, which follows from expression (4) and $s_{M}=0.165$.

Now consider our benchmark model with variable markups. We have that there is pricingto-market, which leads to a movement in the terms of trade in country 1 that is only 53 percent as large as the movement in the PPI-based RER. Using expression (4) with $s_{M}=$ 0.165, the ratio of the movement in the CPI-based RER to that in the PPI-based RER is now 83 percent.

Our finding in the benchmark model that movements in the CPI-based RER are 83 percent as large as movements in the PPI-based RER is an improvement over the models with constant markups or frictionless trade, but still falls short of matching the US data. Recall from Figure 1 that movements in the CPI-based RER have roughly the same magnitudes as movements in the PPI-based RER. We now extend the model to include nontradeable 
distribution costs as a component of consumer prices to examine the performance of our model when these costs are included.

\section{Adding Distribution Costs}

There is an extensive literature on the role of nontradeable distribution costs in accounting for the behavior of international relative prices. In extending our model, we follow Burstein, João C. Neves, and Rebelo (2003) in assuming that final consumption requires adding distribution services in the form of nontradeable goods. Here we model these distribution services directly as a labor input. We now write the aggregator for final consumption as

$$
c_{i}=\left[\int_{0}^{1}\left(y_{i j}^{(1-\phi)} d_{i j}^{\phi}\right)^{1-1 / \eta} d j\right]^{\eta /(\eta-1)},
$$

where $d_{i j}$ is the labor input required for distribution in sector $j$ in country $i$ and $\phi$ is the weight of distribution services in this production technology. Here we assumed that distribution costs account for a constant share of retail prices for each individual good. Under this assumption, pricing-to-market is unchanged relative to our benchmark model. ${ }^{23}$

We choose $\phi=0.5$ based on the gap between total goods consumption at purchaser prices (from US NIPA), and goods production attributed to consumption, at producer prices, as reported in the US Input-Output tables. This gap is roughly 55 percent between 1997 and 2002. It mostly reflects the presence of wholesale and retail trade, a small fraction of transportation costs, and restaurant meals, which are counted as goods in the NIPA's personal consumption expenditure accounts, and as services in the Input-Output tables. This choice is also consistent with the shares reported by Burstein, Neves, and Rebelo (2003).

\footnotetext{
${ }^{23}$ Alternatively, we could assume that the manufactured good and distribution services are combined in fixed proportions. Under this assumption, pricing-to-market is magnified relative to our benchmark model. Corsetti and Dedola (2005) discuss in detail the implications on pricing-to-market under additive distribution costs at the individual good level.
} 
This extended benchmark model generates changes in the CPI-based RER that are 111 percent as large as changes in the PPI-based RER, similar to what is found in the data. Distribution costs have two effects on the CPI-based RER relative to the PPI-based RER. First, they reduce the effective share of imported goods in consumption, and this amplifies changes in relative consumer prices. Second, because distribution is a nontraded component, fluctuations in the relative price of distribution across countries are larger than fluctuations in the PPI-based RER when there is incomplete pass-through of costs to prices, and this also amplifies changes in the CPI-based RER relative to the PPI-based RER.

Note that in our benchmark model, we chose an import share $s_{M}=0.165$ to match the share of trade in manufacturing gross output. We did so to focus on the extent of international competition in US manufacturing and its impact on the pricing decision of firms. One might alternatively choose an import share that reflects the importance of direct imports in consumption. To do so, we recompute our results with an import share equal to $s_{M}=0.225$. This higher import share corresponds to the share of direct imports in consumption of goods (exclusive of retail and wholesale services) calculated from the 1997 US Input/Output accounts. We find that movements in the terms of trade relative to the PPIbased RER are slightly larger than in our benchmark model (59 percent), and movements in the CPI-based RER inclusive of distribution are still large relative to the PPI-based RER (114 percent).

\section{Firm Level Pricing-to-Market}

In our model, deviations from relative PPP at the aggregate level arise as a result of the decisions of individual firms to price-to-market. In this section, we present results from our model on the pricing decisions of individual firms and the role that heterogeneity across firms plays in producing our results.

In our model, each firm's market share and pricing decision depends on the exact configuration of costs across firms in that firm's sector. We find that the heterogeneity of productivities across firms generates a great deal of heterogeneity in pricing. In Figure 3, we 
show the extent of pricing-to-market by each firm that exports from country 1 to country 2 as a function of that firm's market share in country 2. Specifically, on the vertical axis, we plot the change in the logarithm of the ratio of each firm's domestic price $\left(P_{1 j k}\right)$ to its export price $\left(P_{2 j k}\right)$ divided by the change in the overall PPI-based RER in response to the 1 percent increase in aggregate costs in country 1 . Here, a value of zero in the vertical axis indicates that the firm changes its domestic and export price by the same amount. Likewise, a positive value indicates that the firm raises its domestic price by more than its export price in response to the aggregate cost shock.

The figure reveals that there is a great deal of heterogeneity in pricing-to-market at the firm level, even if one holds fixed the exporting firms' market share. Note in the figure that there are a great many firms with small market shares for whom the change in domestic prices relative to export prices is negative or zero, while for the firms with large market shares, this change in domestic prices relative to export prices is positive. Also note that in our model, the aggregate producer price index rises relative to the export price index. This is because these indices compute expenditure share-weighted averages of these price changes so that the large firms dominate the index. These relative movements in aggregate prices are consistent with the aggregate data discussed in Section I, indicating that an increase in home producer prices relative to foreign producer prices is typically associated with an increase in home producer prices relative to export prices. Thus, Figure 3 demonstrates that our finding that our model can generate movements in aggregate price indices similar to those found in the data is accounted for by the pricing behavior of large firms in the model.

Recall that in Table 2 we saw that there was a great deal of variation in the US and Japanese data on the extent of deviations from relative PPP at the sectoral level. In our model, there is also a great deal of heterogeneity across sectors in the extent of deviations from relative PPP. We measure deviations from relative PPP at the sector level in our model as the change in the producer price index relative to the export price index for individual sectors as a percentage of the change in the overall PPI-based RER. We summarize the large 
variation in deviations of relative PPP at the sector level as follows. The median, mean, maximum, minimum, and standard deviation across all sectors are equal to $16,14,58,-38$, and 16 percent, respectively. This variation in pricing across sectors arises entirely as the result of the variation of the configuration of cost realizations for the 40 potentially active firms in each sector. Clearly, even abstracting from other differences across sectors (such as demand elasticities and trade costs), our model generates a great deal of heterogeneity in the extent of deviations from relative PPP at the sectoral level.

The results presented in Figure 3 raise three questions. First, what is the role of heterogeneity in productivities across firms in generating our aggregate results? Second, why do large and small firms price differently? And third, what is the role of the extensive margin in exports in generating our aggregate results?

To begin, we examine pricing decisions of firms within a sector. For notational convenience, we omit subscript $j$. The price and market share of firm $k$ in country $i$ are given by $P_{i k}=\frac{\varepsilon\left(s_{i k}\right)}{\varepsilon\left(s_{i k}\right)-1} w_{i k}$ and $s_{i k}=\left(\frac{P_{i k}}{P_{i}}\right)^{1-\rho}$, where $\varepsilon(s)$ is given by $(16), P_{i}$ is the sectoral price in country $i$, and $w_{i k}$ is the marginal cost of firm $k$ to sell in country $i$. This marginal cost includes the idiosyncratic and aggregate productivities, the aggregate wage, and the variable trade costs for exports. Log-linearizing:

$$
\begin{gathered}
\hat{P}_{i k}=\Gamma\left(s_{i k}\right) \hat{s}_{i k}+\hat{w}_{i k} \\
\hat{s}_{i k}=(1-\rho)\left(\hat{P}_{i k}-\hat{P}_{i}\right)
\end{gathered}
$$

We refer to $\Gamma(s)$ as the elasticity of the markup with respect to market share. Hence, the change in the markup is equal to the product of this elasticity and the change in the market share. In our quantity competition model:

$$
\Gamma(s)=\frac{s}{1-\frac{1}{\rho}(1-s)-\frac{1}{\eta} s}\left(\frac{1}{\eta}-\frac{1}{\rho}\right)
$$


Note that $\Gamma(s)$ is an increasing and convex function of $s$. In the constant markup model, $\Gamma(s)=0$. For a firm based in country $1(k \leq K)$, using the fact that the change in marginal cost is equal for sales to all destinations, the change in the ratio between the export and domestic price is given by

$$
\hat{P}_{1 k}-\hat{P}_{2 k}=\Gamma\left(s_{1 k}\right) \hat{s}_{1 k}-\Gamma\left(s_{2 k}\right) \hat{s}_{2 k} .
$$

As this equation makes clear, there is pricing-to-market when the change in the markup in export prices differs from the change in the markup in domestic prices. Since the change in the markup in each market is the product of the elasticity of the markup with respect to market share and the change in market shares, this pricing-to-market arises when the elasticity of the markup varies with the firm's market share and the firm has different market shares at home and abroad, and/or when these home and export shares respond differently to a shock to aggregate costs.

\section{A. Heterogeneity in Productivities}

We use these equations to show that in the absence of heterogeneity across firms in productivities and export participation, our model does not produce deviations from relative PPP in the direction suggested by the data. To see this, consider a version of our model in which all firms within a sector have identical cost (i.e., $z_{j k}=z$ for all $j, k$ ) and all these firms participate in the export market (i.e., $F$ is small enough). We now show analytically that if $D>1$ so that the import share is less than one-half, then deviations from relative PPP are in the wrong direction in the sense that they imply a negative comovement of $P P I_{1} / E P I_{1}$ and the PPI-based RER. This happens because country 1 firms raise export prices relative to the domestic prices after an increase in their costs relative to costs in country 2. When all firms are identical and $D>1$, all $K$ domestic firms in country 1 have share $s_{11}$ and all $K$ foreign firms have share $s_{1 K+1}$, with $s_{11}>s_{1 K+1}$. Note that $K s_{11}=1-s_{M}$ and $K s_{1 K+1}=s_{M}$.

Suppose that $\frac{\widehat{W_{1}}}{A_{1}}=-\frac{\widehat{W_{2}}}{A_{2}}=0.5$ percent, which implies that country 1's relative costs increase 
by 1 percent. By symmetry, changes in prices and shares of foreign firm sales in one country are equal to the negative of changes in prices and shares of home firms in the other country (e.g., $\hat{P}_{11}=-\hat{P}_{2 K+1}$ and $\left.\hat{s}_{11}=-\hat{s}_{2 K+1}\right)$. Using the fact that $\left(1-s_{M}\right) \hat{s}_{11}+s_{M} \hat{s}_{1 K+1}=0$ (because market shares add up to 1 at all times), we have that $\hat{P}_{21} \leq \hat{P}_{11}$ in response to an increase in costs in country 1 , if and only if $\left(1-s_{M}\right) \Gamma\left(s_{1 K+1}\right)>s_{M} \Gamma\left(s_{11}\right)$. Using the definition of $\Gamma$ (.) in (23), this condition is never satisfied when $s_{11}>s_{1 K+1}$. Hence, without firm heterogeneity, all firms in country 1 increase their export price relative to their domestic price after an increase in their cost of production. This is at odds with the direction of the deviations from relative PPP seen in the aggregate price data. ${ }^{24}$

\section{B. Pricing by Large and Small Firms}

We now turn to the question of why large and small firms choose different prices in response to an aggregate cost shock. In particular, to understand this result that only large firms price-to-market in the right direction, it is useful to examine once again the firm's pricing equations. Substituting (22) into (21):

$$
\hat{P}_{i k}=\frac{1}{1+\Gamma\left(s_{i k}\right)(\rho-1)}\left(\hat{w}_{i k}+\Gamma\left(s_{i k}\right)(\rho-1) \hat{P}_{i}\right)
$$

In this expression, we see that the change in a firm's price can be broken into two components: the change in its price for a given change in its cost, and the change in its price for a given change in its competitors' prices as reflected in the sectoral price $\hat{P}_{i}$. We are interested in the difference in the price change across countries, which can be written as

$$
\begin{aligned}
\hat{P}_{1 k}-\hat{P}_{2 k}= & {\left[\frac{1}{1+\Gamma\left(s_{1 k}\right)(\rho-1)}-\frac{1}{1+\Gamma\left(s_{2 k}\right)(\rho-1)}\right]\left(\hat{w}_{1 k}-\hat{P}_{1}\right) } \\
& +\frac{\Gamma\left(s_{2 k}\right)(\rho-1)}{1+\Gamma\left(s_{2 k}\right)(\rho-1)}\left(\hat{P}_{1}-\hat{P}_{2}\right)
\end{aligned}
$$

\footnotetext{
${ }^{24}$ Ravn (2001) also assumes a nested CES demand structure, but abstracts from within sector cost dispersion and differences in the number of domestic and foreign firms. As we have shown here, this results in pricing-to-market in the opposite direction than what is suggested by aggregate price data.
} 
Under incomplete pass-through of cost changes to prices, $\hat{w}_{1} \geq \hat{P}_{1}$. So, given that $\Gamma($.$) is$ increasing, with $s_{2 k}<s_{1 K}$, the first term is negative. The second term is positive if $\hat{P}_{1}>\hat{P}_{2}$ (which is typically the case with a shock that raises aggregate costs in country 1 relative to country 2), and it becomes more positive as we increase $s$.

The first term in (26) is the direct effect of a change in the firm's costs on its pricing. The force of this effect in our model is in the wrong direction - through this effect a cost shock to a home firm leads it to raise its export price relative to its domestic price. The intuition for this is that since its home market share tends to be larger than its foreign market share, the elasticity of its home markup tends to be larger than the elasticity of its foreign markup, and this leads to more markup adjustment at home than abroad.

The second term in (26) is the effect coming from strategic interactions between firmshow the firm responds to the fact that everyone else is changing their prices. In the standard constant elasticity model, $\Gamma(s)=0$ and this effect is not present. Here, with $\Gamma>0$, we have the standard logic that most people have in mind when they think about pricing-to-market in general equilibrium: in response to a shock that leads to a decrease in the foreign sectoral price level relative to the domestic sectoral price level, an individual firm in the home country wants to cut its markup abroad relative to its markup at home. This effect is strong enough to win out only for those firms with large enough market shares.

We have evaluated the two terms in (26) numerically to understand the dispersion in pricing-to-market behavior, holding fixed export shares, observed in Figure 3. Our numerical results indicate that for firms with small export shares, the dispersion in pricing-to-market arises mainly as a result of dispersion in domestic versus export market shares $\left(s_{1 k}\right.$ and $\left.s_{2 k}\right)$ in the first term in (26). For firms with large export shares, this dispersion in pricing-tomarket arises primarily from dispersion in sectoral price indices across countries $\left(\hat{P}_{1}\right.$ and $\left.\hat{P}_{2}\right)$ in the second term in (26).

\section{The Extensive Margin}

Note that in our analytical argument that a model with no heterogeneity across firms 
has firms pricing-to-market in the wrong direction, we assumed that all firms exported. We now present an example motivated by Dornbusch (1987) in which all firms have identical costs (i.e., $z_{j k}=z$ for all $j, k$ ), but the fixed cost of exporting $F$ is chosen so that only a minority of firms export. We show in this example that it is possible to generate pricingto-market in the right direction in this setting with heterogeneity across firms only in terms of export participation. In our example, we assume that the marginal trade cost $D=1$, so that for all firms that export $s_{1 k}=s_{2 k}$. Using equation (24) and the arguments above that the absolute value of $\hat{s}_{2 k}$ is larger than that of $\hat{s}_{1 k}$ for all exporting firms in country 1 , this gives the result that exporting firms price-to-market in the right direction. ${ }^{25}$ Hence, in our model, it is sufficient to have heterogeneity across firms only in terms of export participation to generate aggregate deviations from relative PPP in the right direction. Of course, this example fails to match several important features of market structure. In particular in this example, exporters have a very high export intensity, they have no size or productivity advantage over non-exporters in terms of domestic sales, and the lack of within-sector cost heterogeneity implies a very low value of the Herfindahl index.

More interesting is the question of whether matching heterogeneity across firms in their export participation is critical quantitatively for the results in our benchmark model. Consider now a version of our model in which we set $F=0$ and, at the same time, raise the marginal export cost $D$ from its benchmark value so as to match again the volume of trade equal to 16.5 percent of production (results are in column 2 of Table 5). Now, all the firms in our model export, and trade is less than the frictionless value of 50 percent only because of the marginal cost of exporting $D$. Note that with this change in parameters, the median Herfindahl index in our model is essentially unchanged. We find that this parameterization of our model with the fixed cost equal to zero gives similar implications for changes in prices as our benchmark model. The terms of trade move only slightly more relative to the PPIbased RER than in the benchmark (56 versus 53 percent). The movement in CPI-based

\footnotetext{
${ }^{25}$ One can also get this result using equation (26). Since $s_{1 k}=s_{2 k}$, the first term in (26) is zero, and firms price-to-market in the right direction since $\hat{P}_{1}>\hat{P}_{2}$.
} 
RER relative to the PPI-based RER is essentially the same as in the benchmark model. This finding arises because the typical non-exporter in our benchmark model with positive fixed costs is so small and because, in response to a shock of only 1 percent to relative costs in country 1 versus country 2, only a few firms switch export status (country 1 firms that stop exporting and the country 2 firms that start exporting account for only 0.2 percent of exports in their respective countries in the symmetric equilibrium).

The extensive margin in export participation becomes more important when the aggregate productivity shock generates a larger movement in relative costs of production across countries. In columns 3 and 4 of Table 5, we show the response of prices in our benchmark model to a shock to aggregate productivity in country 1 large enough to generate a movement in relative costs across countries of 10 percent and 50 percent, respectively. In response to these larger shocks, many more firms switch export status. In the case of the 10 percent shock to relative costs, the country 1 firms that stop exporting and the country 2 firms that start exporting account for nearly 3 percent of exports in their respective countries, whereas in the case of the 50 percent shock to relative costs, these firms account for roughly 40 percent of exports in their respective countries. We see in Table 5 that the results for prices in our benchmark model do not vary that much with the size of the shock. Specifically, the changes in both the terms of trade and the CPI-based RER relative to the change in the PPI-based RER are similar for all three shocks. There are two offsetting effects as the shock gets larger. For the firms in country 1 that continue to export following the shock, they choose less pricing-to-market as the shock gets larger because they are losing more market share. On the other hand, the country 1 firms that stop exporting to country 2 are the firms that were originally small and which tended to price-to-market in the wrong direction in response to a relative cost shock. Because there firms stop exporting, they are no longer included in the export price index. Symmetric arguments apply to the firms in country 2.

These results imply that for small shocks, the extensive margin is not quantitatively important in generating our results. We have also found that our results do not change 
significantly with large shocks to relative costs, despite the fact that these shocks generate large changes in export participation.

\section{Sensitivity Analysis}

Here we examine the sensitivity of our model's implications for pricing to changes in the number of firms per sector, the median Herfindahl index across sectors, and the elasticities $\eta$ and $\rho$.

In our benchmark model we fixed the number of domestic firms per sector, $K$, to 20 . With this parameterization, sectors in our model are quite small (smaller than the average 10-digit NAICS sector). We first examine how our results change with a larger value of $K$.

If we had a continuum of firms in each sector, then each firm would have an infinitesimal market share and markups would be constant at $\rho /(\rho-1)$. Note that it is not necessarily the case that all firms have vanishing market share (and thus a constant markup) as $K$ becomes large but remains finite. There are two effects as $K$ grows. The market share for the typical firm shrinks, but the productivities of the few most productive firms grow. We now show that it is possible to have a much larger value of $K$, here $K=100$, and still have substantial deviations from relative PPP in our model.

We proceed with our analysis in two steps. We first increase $K$ from 20 to 100, keeping the standard deviation of productivity draws $\theta$ constant at our benchmark level, and adjusting $D$ and $F$ to match the same targets on trade volumes and export participation. Here, holding $D$ and $F$ fixed, increasing $K$ leads to lower trade volumes and export participation, so this calibration requires a lower $D$ and $F$ relative to the benchmark model. Under this parameterization, the typical sector is less concentrated, with the median Herfindahl index falling from 1500 to 900 . Column 5 in Table 4 shows that this model produces smaller aggregate deviations from relative PPP in response to a change in relative costs across countries (the terms of trade moves by 67 percent, instead of 53 percent, relative to the PPIbased RER), but these movements are still substantial relative to the model with constant markups (where the ratio is equal to 100 percent). 
In the second step of our analysis, we increase $\theta$ to match the same median Herfindahl index (1500) as in our benchmark model. Column 6 in Table 4 shows that this model produces aggregate deviations from relative PPP that are even larger than in our benchmark model (the movement in the terms of trade relative to the PPI-based RER is now 47 percent).

We conclude that choosing a small value of $K$ is not critical for our findings. Instead, it is important that we have a relatively high value of the Herfindahl index at the sectoral level.

Now we consider sensitivity of our pricing results to the elasticity parameters $\eta$ and $\rho$. From the markup elasticity formula (23), it is clear that our model's implications on pricing-to-market depend on the gap in the elasticity parameters $\eta$ and $\rho$. We consider two alternative parameterizations in which we reduce this gap. In the first (column 7 in Table 4) we set $\eta=1.5$ and $\rho=10$, and in the second (column 8 in Table 4) we set $\eta=1.01$ and $\rho=5$. Both alternative parameterizations produce smaller aggregate deviations from relative PPP (the terms of trade move by 69 and 76 percent, respectively, relative to the PPI-based RER), but these movements are still substantial relative to the model with constant markups.

We finish this section by briefly discussing the sensitivity of our pricing results to two other aspects of our model. We first consider a variant of our model in which firm productivities $z$ are exponentially distributed as in Eaton and Kortum (2002). We find that movements in the terms of trade are smoother than in the lognormal case: they are only 39 percent as large as the movement in the PPI-based RER.

Second, in our model the inclusion of the marginal trade cost $D$ allows us to match the observation that the majority of the domestic production of tradeable goods is also consumed domestically. One can match this observation in a model with no marginal trade costs if one is willing to assume home bias in consumption. We introduce this home bias by decreasing the weight of foreign goods in sectoral output (equation 10). We find that this model gives very similar implications to our benchmark model. 


\section{Conclusions}

In this paper, we have presented a model of international trade and international relative prices that is capable of matching many of the main features of the data on trade and international relative consumer and producer prices. We have found that separation of national markets through trade costs and imperfect competition with variable markups leading to pricing-to-market in those separate markets are both essential for generating deviations from relative PPP at the aggregate level. With these deviations from relative PPP, our model reproduces the smoothness of the terms of trade relative to the PPI-based RER and that the CPI-based RER moves roughly one-to-one with the PPI-based RER.

In solving our model with the extensive margin $(F>0)$, we specified that the driving shock was a change in aggregate productivity so that we could solve for the firms' exporting decisions in general equilibrium. In a model with no extensive margin $(F=0)$, one can solve for equilibrium international relative prices purely as a function of international relative costs. Hence, in such a model, one does not need to specify the source of the shock to relative costs. Hence, the implications of such a model for international relative prices are invariant to assuming either aggregate productivity shocks, or monetary shocks with sticky nominal wages or limited participation, as the driving force of fluctuations in international relative costs.

Our model serves as a useful laboratory to examine which features of market structure are most relevant in generating pricing-to-market. We find that fixed costs of exporting are quantitatively not important for generating pricing-to-market in our benchmark model. We have found instead that within-sector dispersion of market shares across firms is a critical feature of market structure in generating quantitatively significant pricing-to-market.

We see a need for further research concerning the modeling of pricing-to-market by firms. We have found pricing-to-market in a simple variant of the standard CES demand system. This result, however, is sensitive to the details of the model. It would be useful, in further research, to develop a more general theory of this pricing behavior and to compare the 
implications of this theory to micro data on firm level prices.

In this paper we have looked to account for important features of the data on international relative prices in a model in which firms' prices are fully flexible. One advantage of our approach is that our model can generate persistent deviations from relative PPP in response to persistent changes in the relative cost of production across countries. The main alternative approach to account for deviations from relative PPP is based on models of sticky nominal prices. In particular, in these models, it is assumed that some firms set prices in the domestic currency for domestic sales and set prices in the foreign currency for exports. As a result, if these nominal prices are sticky, these firms appear to price-to-market when the nominal exchange rate changes. Thus, in this approach, the problem of accounting for deviations from relative PPP is one of accounting for firms' currency invoicing decisions when they set their sticky prices. ${ }^{26}$ One important question in this framework is, why should currency invoicing decisions with sticky nominal prices be so persistent? Perhaps these decisions are persistent because they are close to being optimal. We see our framework as a natural one for examining this question.

\footnotetext{
${ }^{26}$ See, for example, Engel (2006) and Linda S. Goldberg and Cedric Tille (2005) for a theoretical discussion of firms' invoicing decisions when prices are sticky. See also Gita Gopinath, Oleg Itskhoki, and Roberto Rigobon (2007) for empirical evidence of the relation between firms' currency invoicing decisions and incomplete pass-through for US import prices.
} 


\section{Appendix}

\section{Price Indices}

We measure the change in price indices using expenditure share-weighted averages of the change in individual firm prices. Note that under this procedure, the change in the price index from period $t-1$ to period $t$ includes only the price changes of individual firms that have sales in both of those time periods. Measures of export and import prices using unit values are constructed on the same principle of taking expenditure share-weighted averages of price changes. Sample prices, however, are not collected at the most disaggregated level. Instead, ratios of value to quantity are used in place of price observations at the lowest level of disaggregation. In our model, since we can compute prices for individual goods, we use these prices directly in constructing price indices.

We construct changes in aggregate price indices using the following definitions. In these definitions, subscripts denote country, sector, and firm; variables without primes indicate their level before the aggregate shock (our base year), and variables with primes indicate their level after the aggregate shock.

$$
\begin{gathered}
\frac{P P I D_{1}^{\prime}}{P P I D_{1}}=\frac{1}{1-s_{M}} \int_{0}^{1} s_{1 j} \sum_{k=1}^{K} s_{1 j k} \frac{P_{1 j k}^{\prime}}{P_{1 j k}} d j \\
\frac{P P I D_{2}^{\prime}}{P P I D_{2}}=\frac{1}{1-s_{M}} \int_{0}^{1} s_{2 j} \sum_{k=K+1}^{2 K} s_{2 j k} \frac{P_{2 j k}^{\prime}}{P_{2 j k}} d j \\
\frac{E P I_{1}^{\prime}}{E P I_{1}}=\frac{1}{s_{M}} \int_{0}^{1} s_{2 j} \sum_{k=1}^{K} s_{2 j k} \frac{P_{2 j k}^{\prime}}{P_{2 j k}} d j
\end{gathered}
$$

where $\frac{P_{2 j k}^{\prime}}{P_{2 j k}}=\frac{E P I_{1}^{\prime}}{E P I_{1}}$ if good $k$ is exported in only one period,

$$
\frac{I P I_{1}^{\prime}}{I P I_{1}}=\frac{1}{s_{M}} \int_{0}^{1} s_{1 j} \sum_{k=K+1}^{2 K} s_{1 j k} \frac{P_{1 j k}^{\prime}}{P_{1 j k}} d j
$$

where $\frac{P_{1 j k}^{\prime}}{P_{1 j k}}=\frac{I P I_{1}^{\prime}}{I P I_{1}}$ if good $k$ is imported in only one period, 


$$
\begin{aligned}
& \frac{P P I_{1}^{\prime}}{P P I_{1}}=\left(1-s_{M}\right) \frac{P P I D_{1}^{\prime}}{P P I D_{1}}+s_{M} \frac{E P I_{1}^{\prime}}{E P I_{1}}, \\
& \frac{P P I_{2}^{\prime}}{P P I_{2}}=\left(1-s_{M}\right) \frac{P P I D_{2}^{\prime}}{P P I D_{2}}+s_{M} \frac{I P I_{1}^{\prime}}{I P I_{1}}, \\
& \frac{C P I_{1}^{\prime}}{C P I_{1}}=\left(1-s_{M}\right) \frac{P P I D_{1}^{\prime}}{P P I D_{1}}+s_{M} \frac{I P I_{1}^{\prime}}{I P I_{1}}, \\
& \frac{C P I_{2}^{\prime}}{C P I_{2}}=\left(1-s_{M}\right) \frac{P P I D_{2}^{\prime}}{P P I D_{2}}+s_{M} \frac{E P I_{1}^{\prime}}{E P I_{1}},
\end{aligned}
$$

where

$$
s_{i j}=\frac{P_{i j} y_{i j}}{P_{i} c_{i}}
$$

and

$$
s_{M}=\int_{0}^{1} s_{1 j} \sum_{k=K+1}^{2 K} s_{1 j k} d j
$$




\section{REFERENCES}

Alessandria, George. 2004. "International Deviations from the Law of One Price: The Role of Search Frictions and Market Share." International Economic Review, 45(4): $1263-1291$.

Alvarez, Fernando, and Robert E. Lucas Jr. 2007. "General Equilibrium Analysis of the Eaton-Kortum Model of International Trade." Journal of Monetary Economics, 54(6): 1726-1768.

Anderson, James E., and Eric van Wincoop. 2004. "Trade Costs." Journal of Economic Literature, 42(3): 691-751.

Atkeson, Andrew, and Ariel Burstein. 2007. "Pricing-to-Market in a Ricardian Model of International Trade." American Economic Review, 97(2): 362-367.

Backus, David K., and Mario J. Crucini. 2000. "Oil Prices and the Terms of Trade." Journal of International Economics, 50(1): 185-213.

Backus, David K., Patrick J. Kehoe, and Finn Kydland. 1995. "International Business Cycles: Theory vs. Evidence." In Frontiers of Business Cycle Research, ed. Thomas F. Cooley, 331-356. Princeton: Princeton University Press.

Bergin, Paul R., and Robert C. Feenstra. 2001. "Pricing-to-Market, Staggered Contracts, and Real Exchange Rate Persistence." Journal of International Economics, 54(2): $333-359$.

Bergin, Paul R., and Reuven Glick. 2003. "Endogenous Nontradability and Macroeconomic Implications." National Bureau of Economic Research Working Paper 9739.

Bernard, Andrew B., Jonathan Eaton, J. Bradford Jensen, and Samuel Kortum. 2003. "Plants and Productivity in International Trade." American Economic Review, 93(4): 1268-1290. 
Bernard, Andrew B., and J. Bradford Jensen. 2004. "Entry, Expansion, and Intensity in the US Export Boom 1987-1992." Review of International Economics, 12(4): $662-675$.

Betts, Caroline, and Michael B. Devereux. 2000. "Exchange Rate Dynamics in a Model of Pricing-to-Market." Journal of International Economics, 50(1): 215-244.

Betts, Caroline M., and Timothy J. Kehoe. 2006. "US Real Exchange Rate Fluctuations and Relative Price Fluctuations." Journal of Monetary Economics, 53(7): $1297-1326$.

Bodnar, Gordon M., Bernard Dumas, and Richard C. Marston. 2002. "Passthrough and Exposure." Journal of Finance, 57(1): 199-231.

Burstein, Ariel, Martin Eichenbaum, and Sergio Rebelo. 2005. "Large Devaluations and the Real Exchange Rate." Journal of Political Economy, 113(4): 742-784.

Burstein, Ariel T., João C. Neves, and Sergio Rebelo. 2003. "Distribution Costs and Real Exchange Rate Dynamics During Exchange-Rate-Based Stabilizations." Journal of Monetary Economics, 50(6): 1189-1214.

Chaney, Thomas. Forthcoming. "Distorted Gravity: The Intensive and Extensive Margins of International Trade." American Economic Review.

Chari, V.V., Patrick J. Kehoe, and Ellen R. McGrattan. 2002. "Can Sticky Price Models Generate Volatile and Persistent Real Exchange Rates?" Review of Economic Studies, 69(3): 533-563.

Christiano, Lawrence J., Martin Eichenbaum, and Charles L. Evans. 2005. "Nominal Rigidities and the Dynamic Effects of a Shock to Monetary Policy." Journal of Political Economy, 113(1): 1-45. 
Corsetti, Giancarlo, and Luca Dedola. 2005. "A Macroeconomic Model of International Price Discrimination." Journal of International Economics, 67(1): 129-155.

Dornbusch, Rudiger, Stanley Fischer, and Paul A. Samuelson. 1977. "Comparative Advantage, Trade, and Payments in a Ricardian Model with a Continuum of Goods." American Economic Review, 67(5): 823-839.

Dornbusch, Rudiger S. 1987. "Exchange Rates and Prices." American Economic Review, 77(1): 93-106.

Eaton, Jonathan, and Samuel Kortum. 2002. "Technology, Geography, and Trade." Econometrica, 70(5): 1741-1779.

Eaton, Jonathan, Samuel Kortum, and Francis Kramarz. 2004. "An Anatomy of International Trade: Evidence from French Firms." New York University Working Paper.

Engel, Charles. 1999. "Accounting for US Real Exchange Rate Changes." Journal of Political Economy, 107(3): 507-538.

Engel, Charles. 2002. "Expenditure Switching and Exchange Rate Policy." In NBER Macroeconomics Annual 2002, ed. Mark Gertler and Kenneth S. Rogoff, 231-272. Cambridge: MIT Press.

Engel, Charles. 2006. "Equivalence Results for Optimal Pass-Through, Optimal Indexing to Exchange Rates, and Optimal Choice of Currency for Export Pricing." Journal of the European Economic Association, 4(6): 1249-1260.

Feenstra, Robert C., Joseph E. Gagnon, and Michael M. Knetter. 1996. "Market Share and Exchange Rate Pass-Through in World Automobile Trade." Journal of International Economics, 40(1-2): 187-207. 
Fitzgerald, Doireann. Forthcoming. "A Gravity View of Exchange Rate Disconnect." Journal of Monetary Economics.

Ghironi, Fabio, and Marc J. Melitz. 2005. "International Trade and Macroeconomic Dynamics with Heterogeneous Firms." Quarterly Journal of Economics, 120(3): 865915.

Goldberg, Linda S., and Cedric Tille. 2005. "Vehicle Currency Use in International Trade." Federal Reserve Bank of New York Staff Report 200.

Goldberg, Pinelopi K., and Michael M. Knetter. 1997. "Goods Prices and Exchange Rates: What Have We Learned?" Journal of Economic Literature, 35(3): 1243-1272.

Gopinath, Gita, Oleg Itskhoki, and Roberto Rigobon. 2007. "Currency Choice and Exchange Rate Pass-Through." National Bureau of Economic Research Working Paper 13432.

Hellerstein, Rebecca. 2006. "A Decomposition of the Sources of Incomplete CrossBorder Transmission." Federal Reserve Bank of New York Staff Report 250.

Helpman, Elhanan, and Paul R. Krugman. 1985. Market Structure and Foreign Trade: Increasing Returns, Imperfect Competition, and the International Economy. Cambridge: MIT Press.

Knetter, Michael M. 1989. "Price Discrimination by US and German Exporters." American Economic Review, 79(1): 198-210.

Knetter, Michael M. 1993. "International Comparisons of Price-to-Market Behavior." American Economic Review, 83(3): 473-486.

Krugman, Paul R. 1987. "Pricing to Market When the Exchange Rate Changes," in Real-Financial Linkages among Open Economies, ed. Sven W. Arndt and J. David Richardson, 49-70. London: MIT Press. 
Lapham, Beverly J. 1995. "A Dynamic General Equilibrium Analysis of Deviations from the Laws of One Price." Journal of Economic Dynamics and Control, 19(8): 1355-1389.

Marston, Richard C. 1990. "Pricing to Market in Japanese Manufacturing." Journal of International Economics, 29(3-4): 217-236.

Melitz, Marc J. 2003. "The Impact of Trade on Intra-Industry Reallocations and Aggregate Industry Productivity." Econometrica, 71(6): 1695-1725.

Obstfeld, Maurice, and Kenneth Rogoff. 2000. "The Six Major Puzzles in International Economics: Is There a Common Cause?" National Bureau of Economic Research Working Paper 7777.

Ravn, Morten O. 2001. "Imperfect Competition and Prices in a Dynamic Trade Model with Comparative Advantage." European University Institute Working Paper.

Stockman, Alan C., and Linda L. Tesar. 1995. "Tastes and Technology in a TwoCountry Model of the Business Cycle: Explaining International Comovements." American Economic Review, 85(1): 168-185.

Yang, Jiawen. 1997. "Exchange Rate Pass-Through in US Manufacturing Industries." Review of Economics and Statistics, 79(1): 95-104. 
Table 1

Volatility and Correlation of Manufacturing International Relative Prices

Standard deviation relative to PPI / PPI*

\begin{tabular}{cccc}
$\begin{array}{c}\mathbf{1} \\
\text { EPI } / \text { IPI }\end{array}$ & $\begin{array}{c}\mathbf{2} \\
\text { PPI / EPI }\end{array}$ & $\begin{array}{c}\mathbf{3} \\
\text { IPI / PPI* }\end{array}$ & $\begin{array}{c}\mathbf{4} \\
\text { CPI / CP }\end{array}$ \\
\hline \hline & & & \\
0.38 & 0.27 & 0.68 & 1.08 \\
0.46 & 0.32 & 0.67 & 1.10 \\
0.45 & 0.53 & 0.42 & 1.08 \\
0.58 & 0.38 & 0.69 & 0.95 \\
0.39 & 0.64 & 0.66 & 0.9 \\
0.65 & 0.69 & 0.72 & 1.1 \\
0.37 & 0.44 & 0.63 & 1.12 \\
0.66 & 0.50 & 0.57 & 1.27
\end{tabular}

0.50

0.57

\section{Correlation with PPI / PPI*}

$\mathrm{CPI} *$

EPI / IPI

6

PPI / EPI

PI 7

Panel A: Yearly differences

United States, 1985-2006

United States, 1975-2006

Japan, 1975-2006

Germany, 1975-2003

France, 1975-2003

Italy, 1981-2003

United Kingdom, 1975-2003

Canada, 1975-2003

1.27

0.71
0.66
0.53
0.73
0.23
0.31
0.50
0.58

0.57

0.45

0.87

0.24

0.70

0.59

0.62

0.63

$\begin{array}{ll}0.84 & 0.98 \\ 0.82 & 0.97 \\ 0.72 & 0.99 \\ 0.70 & 0.97 \\ 0.70 & 0.81 \\ 0.54 & 0.98 \\ 0.86 & 0.96 \\ 0.53 & 0.85\end{array}$

\section{Panel B: HP-filtered quarterly data}

United States, 1985-2006

United States, 1975-2006

Japan, 1975-2006

Germany, 1975-2003

France, 1975-2003

Italy, 1981-2003

United Kingdom, 1975-2003

Canada, 1975-2003

$\begin{array}{ll}0.35 & 0.35 \\ 0.46 & 0.34 \\ 0.42 & 0.51 \\ 0.58 & 0.35 \\ 0.36 & 0.58 \\ 0.62 & 0.66 \\ 0.39 & 0.48 \\ 0.60 & 0.49\end{array}$

$\begin{array}{ll}0.61 & 1.04 \\ 0.60 & 1.02 \\ 0.44 & 1.09 \\ 0.64 & 0.96 \\ 0.68 & 0.95 \\ 0.70 & 1.07 \\ 0.56 & 1.18 \\ 0.57 & 1.24\end{array}$

0.76
0.72
0.53
0.76
0.29
0.39
0.53
0.54

0.70
0.55
0.89
0.23
0.67
0.53
0.65
0.65

0.79

0.81

0.97

$0.34-1.02-0.72$

0.81
0.74

0.96

1.09
0.96

0.95

0.75

0.99

0.23

0.74

$0.48 \quad 0.56$

0.53

0.59

0.86

(1)

Note: All prices are quarterly and measured in US dollars. PPI: Manufacturing producer price index, PPI*: Trade-weighted manufacturing producer price index, EPI: Manufacturing export price index, IPI: Manufacturing import price index, CPI: Consumer price index (goods for US 1985-2006, goods + services for the rest),

CPI*: Trade-weighted consumer price index (goods for US's 1985-2006 trading partners, and goods + services for the rest).

Sources: United States: EPI and IPI from Source OECD (1975-1985) and BLS (1986-2006), CPI and PPI from BLS; Japan: EPI, IPI, and PPI from Bank of Japan, CPI from Source OECD;

United Kingdom: EPI, IPI, and PPI from UK National Statistics, CPI from Source OECD; Germany, France, Italy, and Canada: EPI, IPI, PPI, and CPI from Source OECD.

Choice of trade partners is subject to data availability: US, Japan, Germany, France, Italy, UK, Canada, Australia, Austria, Belgium, Denmark, Finland, Greece, Ireland, South Korea, Mexico, Netherlands, New Zealand, Norway, Portugal, Spain, Sweden, Switzerland, Singapore, Indonesia, Malaysia, Philippines, Thailand, and India.

All price indices for remaining trade partners from Source OECD and IFS, except for Mexico (Banco de Mexico) and South Korea (Bank of Korea). Trade weights from OECD. 
Table 2

Volatility and Correlation of Disaggregated International Relative Prices

Panel A: US import prices by source country $i$

Manufacturing industries

HP filtered quarterly, 1991-2006

(IPI source i / PPI i) and (PPI US / PPI i)

Ratio of standard Correlations

deviations

$\begin{array}{lll}\text { Japan } & 0.85 & 0.97 \\ \text { EU } & 0.78 & 0.98 \\ \text { Canada } & 0.83 & 0.85\end{array}$

Source: Import prices and US PPI from BLS, foreign PPI and trade weights from OECD.

\section{Panel B: US export prices by SIC industry j}

39 four-digit manufacturing SIC industries, exports to all destinations HP filtered quarterly, 1980-1992, subject to data availability by sector j

(PPI US j / EPI US j ) and (aggregate PPI US / aggregate PPI* trade weighted)

Statistics Ratio of standard Correlations

across sectors deviations

Median $\quad 0.36 \quad 0.19$

Mean $\quad 0.49 \quad 0.16$

Maximum $\quad 2.23 \quad 0.68$

Minimum $\quad 0.18 \quad-0.58$

Standard deviation $\quad 0.40 \quad 0.33$

Source: US export and producer prices from BLS, foreign PPI and trade weights from OECD.

Panel C: Japanese export prices by major manufacturing industry j

HP filtered quarterly, 1975-2006

(PPI Jap j / EPI Jap j ) and (aggregate PPI Jap / aggregate PPI* trade weighted)

$\begin{array}{lll}\begin{array}{l}\text { Statistics } \\ \text { across sectors }\end{array} & \begin{array}{l}\text { Ratio of standard } \\ \text { deviations }\end{array} & \text { Correlations }\end{array}$

$\begin{array}{lll}\text { Textiles } & 0.59 & 0.73\end{array}$

$\begin{array}{lll}\text { Chemicals and related products } & 1.02 & 0.73\end{array}$

$\begin{array}{lll}\text { Metals and related products } & 0.97 & 0.74\end{array}$

$\begin{array}{lll}\text { General machinery and equipment } & 0.38 & 0.92\end{array}$

$\begin{array}{lll}\text { Electrical machinery and equipment } & 0.63 & 0.92\end{array}$

$\begin{array}{lll}\text { Transportation equipment } & 0.66 & 0.90\end{array}$

$\begin{array}{lll}\text { Precision Instruments } & 0.41 & 0.49\end{array}$

Source: Japanese export and producer prices from Bank of Japan, foreign PPI and trade weights from OECD. 
Table 3

Parameter Values and Symmetric Equilibrium Implications

\section{Panel A: Parameter values}

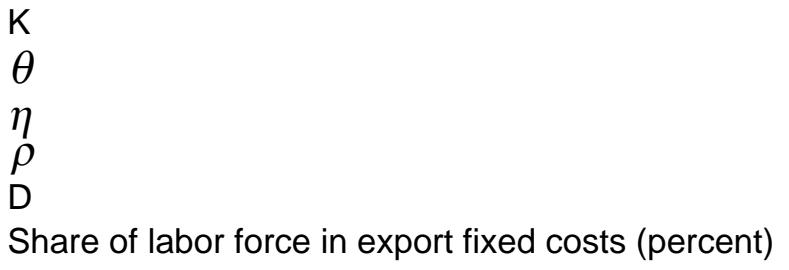

$\begin{array}{ccc}20 & 20 & 20 \\ 0.385 & 0.385 & 0.385 \\ 1.01 & 3.5 & 1.01 \\ 10.0 & 3.5 & 10.0 \\ 1.45 & 1.58 & 1.00 \\ 0.08 & 1.33 & 0.00\end{array}$

\section{Panel B: Symmetric equilibrium implications}

Exports / Manufacturing Gross Output (percent)

Fraction of exporting firms (percent)

Median exporter's intensity (percent)

Average domestic exporter's sales / Average non-exporter's sales

Average exporter's - non-exporter's log value added per worker (percent)

Median Herfindahl index

Weighted average markup (percent)

\section{Benchmark model}

Constant

markup
16.6

24.8

16.6

25.6

24.3

4.8

14.9

12.5

1502

28.9
3

\section{Frictionless}

trade

Note: BJ: Bernard and Jensen (2004), BEJK: Bernard et al. (2003), EKK: Eaton, Kortum, and Kramarz (2004)

\section{US Data Source}

$$
\text { 16.5 US Input-Output }
$$$$
25.0 \text { BJ }
$$

$<10$ BEJK

4.8 - 28 BEJK and EKK

[15-33] BEJK 
Table 4

Implications of Model: 1 Percent Increase in (W1/A1) I (W2/A2)

\begin{tabular}{|c|c|c|c|}
\hline & $\begin{array}{c}1 \\
\text { Benchmark } \\
\text { model }\end{array}$ & $\begin{array}{c}2 \\
\text { Constant } \\
\text { markup }\end{array}$ & $\begin{array}{c}3 \\
\text { Frictionless } \\
\text { trade }\end{array}$ \\
\hline \multicolumn{4}{|l|}{ Panel A: Terms of trade and PPI-based-RER } \\
\hline \multicolumn{4}{|l|}{$\widehat{P P I_{1}}-\widehat{P P I_{2}}$ decomposition (percent contribution) } \\
\hline $1 \widehat{E P I_{1}}-\widehat{I P I_{1}}$ & 53.4 & 100.0 & 100.0 \\
\hline $2 \widehat{P P I_{1}}-\widehat{E P I_{1}}$ & 23.1 & 0.0 & 0.0 \\
\hline $3 \widehat{I P I_{1}}-\widehat{P P I_{2}}$ & 23.6 & 0.0 & 0.0 \\
\hline \multicolumn{4}{|l|}{ Change in price indices (percent) } \\
\hline $4 \widehat{P P I_{1}}$ & 0.86 & 1.00 & 0.76 \\
\hline $5 \widehat{E P I_{1}}$ & 0.69 & 1.00 & 0.76 \\
\hline $6 \widehat{I P I_{1}}$ & 0.31 & 0.00 & 0.23 \\
\hline $7 \widehat{P P I_{2}}$ & 0.14 & 0.00 & 0.23 \\
\hline \multicolumn{4}{|l|}{ Panel B: CPI-based-RER (percent) } \\
\hline $8\left(\widehat{C P I}_{1}-\widehat{C P I}_{2}\right) /\left(\widehat{P P I}_{1}-\widehat{P P I}_{2}\right) \quad$ (excluding distribution; & 82.3 & 66.9 & 0.0 \\
\hline
\end{tabular}


Table 5: Sensitivity Analysis

\begin{tabular}{|c|c|c|c|c|c|c|c|c|}
\hline & $\begin{array}{c}1 \\
\text { Benchmark } \\
\text { model }\end{array}$ & $\begin{array}{c}2 \\
\text { All firms export } \\
F=0\end{array}$ & $\begin{array}{c}3 \\
10 \text { percent } \\
\text { change in } \\
\text { relative costs }\end{array}$ & $\begin{array}{c}4 \\
50 \text { percent } \\
\text { change in } \\
\text { relative costs }\end{array}$ & \begin{tabular}{c}
\multicolumn{1}{c}{5} \\
$\mathrm{~K}=100$ \\
$\theta \quad$ at \\
benchmark
\end{tabular} & $\begin{array}{c}6 \\
K=100 \\
\text { Herfindahl }= \\
1500\end{array}$ & $\begin{array}{c}7 \\
\eta=1.5\end{array}$ & $\begin{array}{c}8 \\
\rho=10\end{array}$ \\
\hline \multicolumn{9}{|l|}{ Panel A: Parameter values } \\
\hline $\mathrm{K}$ & 20 & 20 & 20 & 20 & 100 & 100 & 20 & 20 \\
\hline$\theta$ & 0.39 & 0.39 & 0.39 & 0.39 & 0.39 & 0.57 & 0.31 & 0.64 \\
\hline$\eta$ & 1.01 & 1.01 & 1.01 & 1.01 & 1.01 & 1.01 & 1.50 & 1.01 \\
\hline$\rho$ & 10 & 10 & 10 & 10 & 10 & 10 & 10 & 5 \\
\hline $\mathrm{D}$ & 1.45 & 1.46 & 1.45 & 1.45 & 1.34 & 1.48 & 1.35 & 1.85 \\
\hline Share of labor force in export fixed costs & 0.08 & 0.00 & 0.08 & 0.08 & 0.03 & 0.00 & 0.11 & 0.27 \\
\hline \multicolumn{9}{|l|}{ Panel B: Symmetric equilibrium implications } \\
\hline Exports / Manufacturing Gross Output & 16.6 & 16.7 & 16.6 & 16.6 & 16.5 & 16.6 & 16.5 & 16.6 \\
\hline Fraction of exporting firms & 24.8 & 100.0 & 24.8 & 24.8 & 25.0 & 25.3 & 24.8 & 25.2 \\
\hline Median Herfindahl index & 1502 & 1493 & 1502 & 1502 & 900 & 1498 & 1513 & 1516 \\
\hline Weighted average markup & 29 & 29 & 29 & 29 & 21 & 29 & 22 & 42 \\
\hline Panel C: Change in relative marginal costs (percent) & 1 & 1 & 10 & 50 & 1 & 1 & 1 & 1 \\
\hline \multicolumn{9}{|l|}{$\widehat{P P I_{1}}-\widehat{P P I_{2}}$ decomposition (percent contribution) } \\
\hline$\widehat{E P I_{1}}-\widehat{I P I_{1}}$ & 53.4 & 55.9 & 53.2 & 55.1 & 67.5 & 46.9 & 68.9 & 76.3 \\
\hline$\widehat{P P I_{1}}-\widehat{E P I_{1}}$ & 23.1 & 21.8 & 20.6 & 16.1 & 15.7 & 26.1 & 15.3 & 11.7 \\
\hline$\widehat{I P I_{1}}-\widehat{P P I_{2}}$ & 23.6 & 22.3 & 26.2 & 28.8 & 16.8 & 27.0 & 15.9 & 12.0 \\
\hline$\left(\widehat{C P I_{1}}-\widehat{C P I_{2}}\right) /\left(\widehat{P P I}_{1}-\widehat{P P I}_{2}\right) \quad$ (excluding distribution) & 82.3 & 81.4 & 82.6 & 86.4 & 77.7 & 84.4 & 77.3 & 74.7 \\
\hline
\end{tabular}


Figure 1: U.S., Terms of Trade and Trade-Weighted Real Exchange Rates

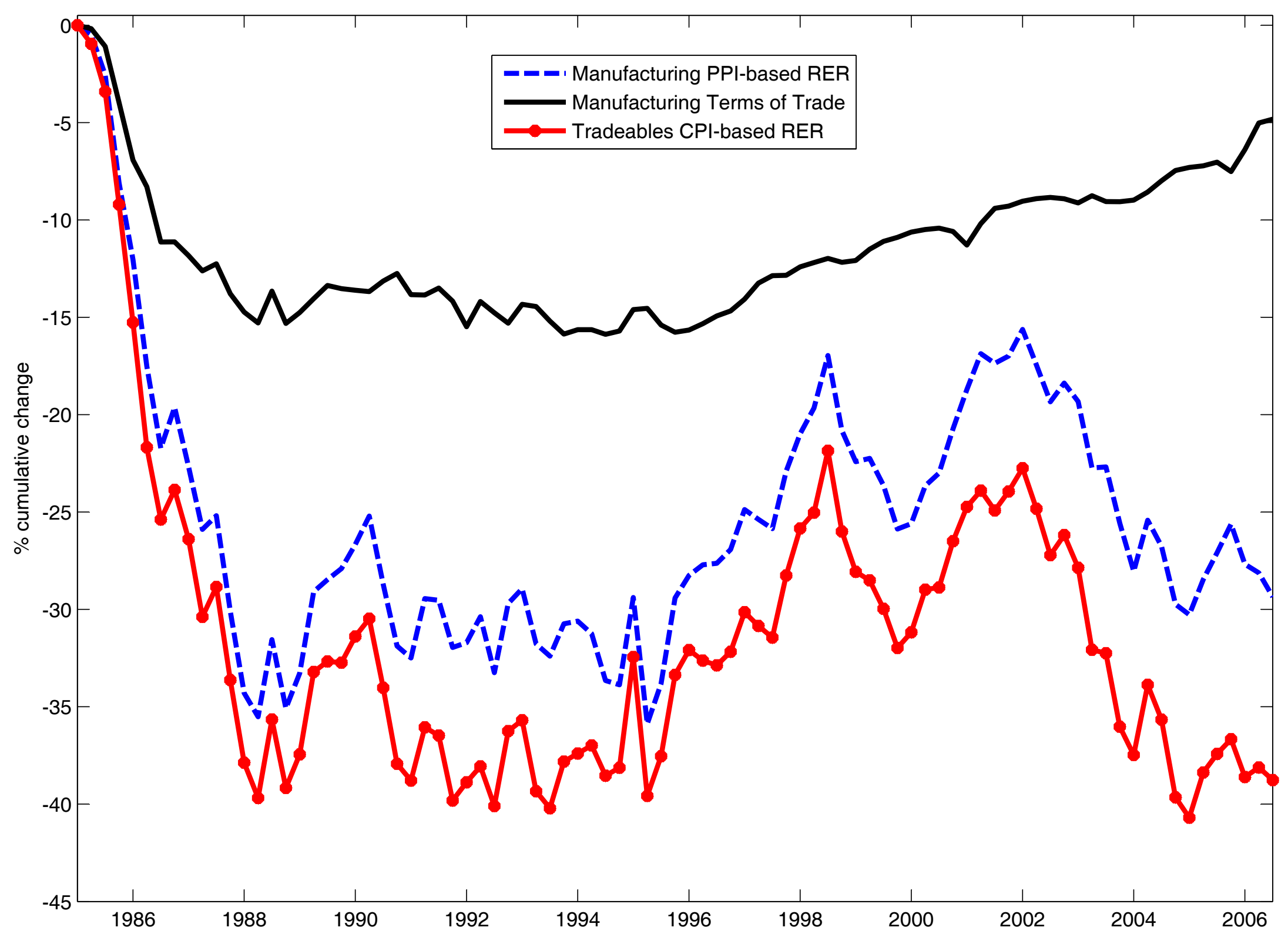

Source of data: See Table 1 
Figure 2: Symmetric equilibrium: markups and Herfindahl indices

Histogram of sectoral Herfindahl indices

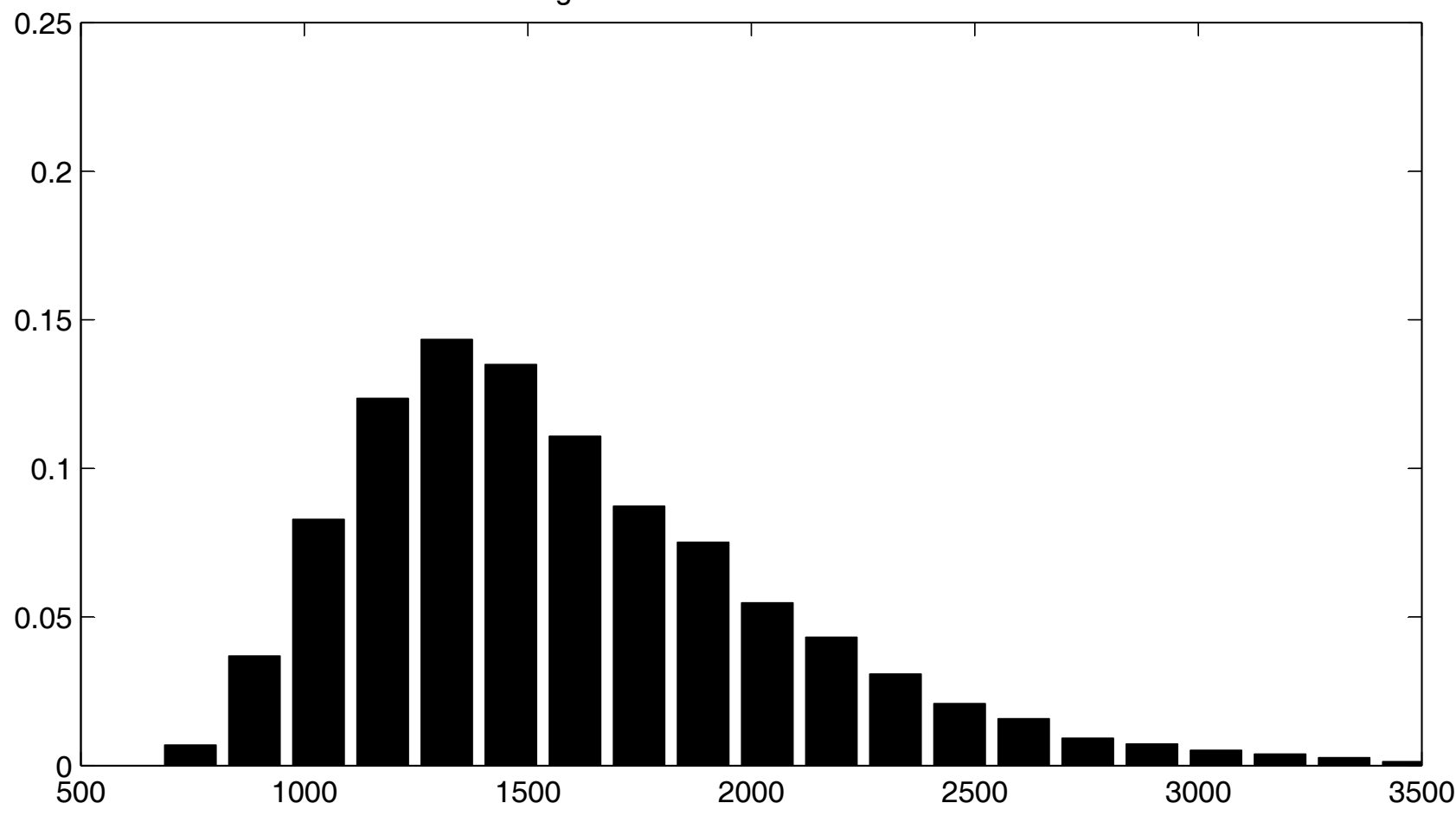

Histogram of firm markups

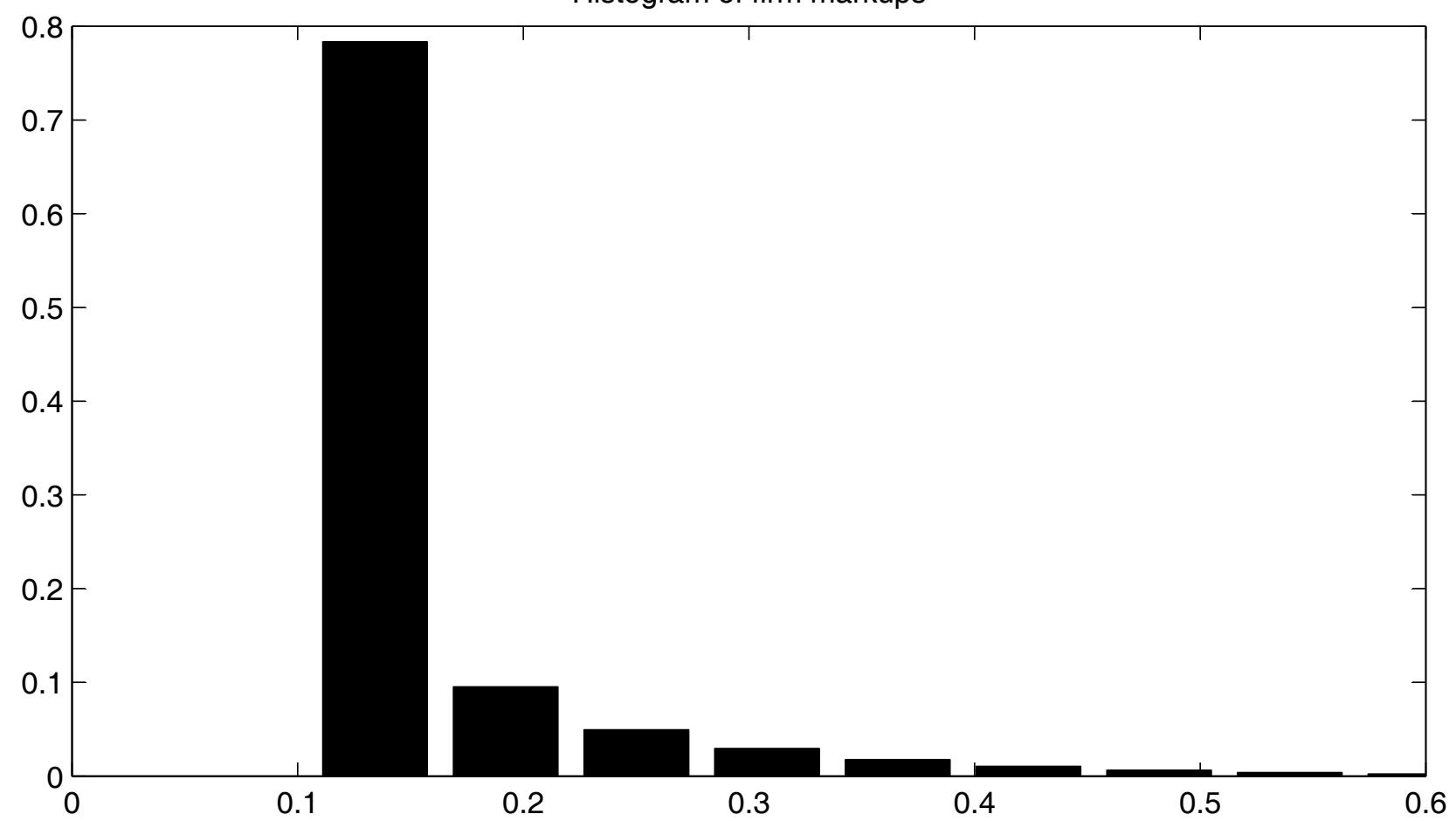




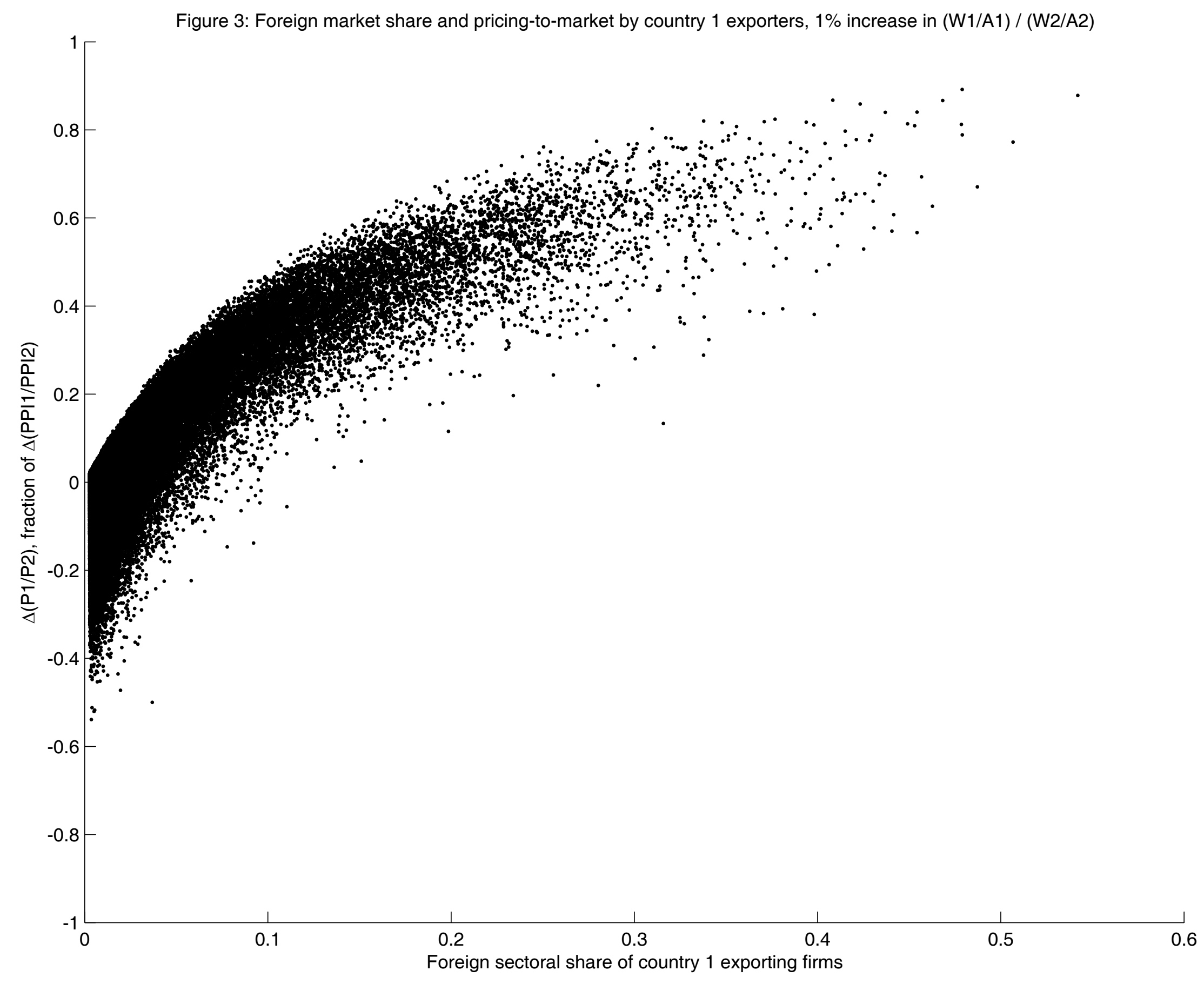

